\title{
Phytoplankton growth, microzooplankton herbivory and community structure in the southeast Bering Sea: insight into the formation and temporal persistence of an Emiliania huxleyi bloom
}

\author{
M. Brady Olson*, Suzanne L. Strom \\ Shannon Point Marine Center, Western Washington University, 1900 Shannon Point Road, Anacortes, WA 98221, USA
}

\begin{abstract}
Using the seawater dilution technique, we measured phytoplankton growth and microzooplankton grazing rates within and outside of the 1999 Bering Sea coccolithophorid bloom. We found that reduced microzooplankton grazing mortality is a key component in the formation and temporal persistence of the Emiliania huxleyi bloom that continues to proliferate in the southeast Bering Sea. Total chlorophyll $a(\mathrm{Chl} a)$ at the study sites ranged from 0.40 to $4.45 \mu \mathrm{g} \mathrm{Cl}^{-1}$. Highest phytoplankton biomass was found within the bloom, which was a mixed assemblage of diatoms and E. huxleyi. Here, $75 \%$ of the $\mathrm{Chl} a$ came from cells $>10 \mu \mathrm{m}$ and was attributed primarily to the high abundance of the diatom Nitzschia spp. Nutrient-enhanced total phytoplankton growth rates averaged $0.53 \mathrm{~d}^{-1}$ across all experimental stations. Average growth rates for $>10 \mu \mathrm{m}$ and $<10 \mu \mathrm{m}$ cells were nearly equal, while microzooplankton grazing varied among stations and size fractions. Grazing on phytoplankton cells $>10 \mu \mathrm{m}$ ranged from 0.19 to $1.14 \mathrm{~d}^{-1}$. Grazing on cells $<10 \mu \mathrm{m}$ ranged from 0.02 to $1.07 \mathrm{~d}^{-1}$, and was significantly higher at non-bloom (avg. $0.71 \mathrm{~d}^{-1}$ ) than at bloom (avg. $0.14 \mathrm{~d}^{-1}$ ) stations. Averaged across all stations, grazing by microzooplankton accounted for $110 \%$ and $81 \%$ of phytoplankton growth for $>10$ and $<10 \mu \mathrm{m}$ cells, respectively. These findings contradict the paradigm that microzooplankton are constrained to diets of nanophytoplankton and strongly suggests that their grazing capability extends beyond boundaries assumed by size-based models. Dinoflagellates and oligotrich ciliates dominated the microzooplankton community. Estimates of abundance and biomass for microzooplankton $>10 \mu \mathrm{m}$ were higher than previously reported for the region, ranging from 22,000 to 227,430 cells ${ }^{-1}$ and 18 to $164 \mu \mathrm{g} \mathrm{Cl}^{-1}$. Highest abundance and biomass occurred in the bloom and corresponded with increased abundance of the large ciliate Laboea, and the heterotrophic dinoflagellates Protoperidinium and Gyrodinium spp. Despite low grazing rates on phytoplankton $<10 \mu \mathrm{m}$ within the bloom, the abundance and biomass of small microzooplankton $(<20 \mu \mathrm{m})$ capable of grazing $E$. huxleyi was relatively high at bloom stations. This body of evidence, coupled with observed high grazing rates on large phytoplankton cells, suggests the phytoplankton community composition was strongly regulated by herbivorous activity of microzooplankton. Because grazing behavior deviated from size-based model predictions and was not proportional to microzooplankton biomass, alternate mechanisms that dictate levels of grazing activity were in effect in the southeastern Bering Sea. We hypothesize that these mechanisms included morphological or chemical signaling between phytoplankton and micrograzers, which led to selective grazing pressure.
\end{abstract}

(C) 2002 Elsevier Science Ltd. All rights reserved.

\footnotetext{
*Corresponding author.

E-mail addresses: olsonm@cc.wwu.edu (M.B. Olson).
} 


\section{Introduction}

The southeastern Bering Sea is a biologically rich ecosystem whose high productivity is, in part, the result of complex physical-chemical interactions occurring over the broad, shallow continental shelf (Springer et al., 1996) that comprises $\sim 50 \%$ of the total Bering Sea area. These interactions, which include water-column stratification from sea-ice melt (Alexander and Niebauer, 1981), eddies, and wind-driven vertical mixing of nutrients into surface waters, provide the components necessary for high primary productivity.

Diatoms typically dominate phytoplankton biomass in the Bering Sea (Sukhanova et al., 1999). Classic food web models of the Bering Sea show diatom-produced biomass being transferred through crustacean zooplankton (Hood, 1999), ultimately supporting one of the world's largest fisheries (Loughlin et al., 1999). However, this classic model is in need of revision. Recent studies show that some copepods preferentially feed on dinoflagellates and microzooplankton over diatoms (Stoecker and Capuzzo, 1990; Kleppel et al., 1991), which can be a sub-optimal food source for copepods. In one study, diatoms reduced fecundity by an average of $87 \%$ compared to non-diatom prey (Ban et al., 1997). In another study, hatching success was only $12 \%$ among copepods in a diatom-dominated bloom compared to $90 \%$ in post-bloom conditions (Miralto et al., 1999). Miralto et al. (1999) also isolated three antiproliferative aldehydes from the diatoms Thalassiosira rotula, Skeletonema costatum, and Pseudonitzschia delicatissima that caused low hatching success in the copepod Temora stylifera.

If diatoms are a sub-optimal diet for copepods and other crustacean zooplankton, what supports the high crustacean biomass in the southeastern Bering Sea? Microzooplankton, a component of the marine plankton consisting of protists and metazoa $<200 \mu \mathrm{m}$ (Dussart, 1965) may be the answer. Microzooplankton display unique feeding mechanisms and behaviors that allow them to graze cells up to five times their own volume (Jacobson and Anderson, 1986; Hansen and Calado, 1999). They are capable of grazing bacteria (Sherr and Sherr, 1994) and transporting bacterial biomass out of the microbial loop (Sherr and Sherr, 1988). They can grow at rates which equal or exceed prey growth (Sherr and Sherr, 1994) and can serve as a viable food source for metazoans (Gifford, 1991; Stoecker and Capuzzo, 1990).

Because microzooplankton are individually inconspicuous, their recognition as significant consumers of oceanic primary production has come only in the last 20 years. Consequently, quantitative studies of microzooplankton herbivory are limited to a few regions of the world's oceans. These studies show that microzooplankton can be the dominant consumers of phytoplankton production in both oligo- and eutrophic regions of the ocean (Capriulo et al., 1991; Sherr and Sherr, 1992; Lessard and Murrell, 1998) and are capable of consuming $>100 \%$ of primary production (Gifford, 1988; Burkill et al., 1993; Verity et al., 1996; Lessard and Murrell, 1998; Strom et al., 2001). However, little is known of microzooplankton feeding ecology as it pertains to phytoplankton bloom formation and persistence.

Unusual climatic conditions in 1997 and 1998, including warmer-than-average sea temperatures (Hunt et al., 1999), were coincident with the first recorded bloom of the prymnesiophyte Emiliania huxleyi in the Bering Sea (Vance et al., 1998). The unexpected appearance of an E. huxleyi bloom in the Bering Sea is interesting; however, equally puzzling is the large spatial and temporal extent of the bloom.

One explanation for the persistence of the bloom may relate to the functional morphology of E. huxleyi. E. huxleyi, like all coccolithophores, produces calcium carbonate plates (coccoliths) that surround the cell. Besides altering the optical properties of the water (i.e. scattering light, thus reducing available PAR for phytoplankton deeper in the water column), these coccoliths may regulate the amount of light available to the cell; this capability allows E. huxleyi to live high in the water column (Young, 1994) where photoinhibition may limit growth of competing species of phytoplankton. This ability, coupled with the capacity to thrive at low nutrient concentrations (Nejstgaard et al., 1997), may give E. huxleyi a competitive advantage over larger phytoplankton 
species that typically dominate in the Bering Sea. However, this does not explain why microzooplankton herbivory does not reduce the standing crop of E. huxleyi. Because microzooplankton are capable of grazing $100 \%$ of phytoplankton production, the longevity of the bloom suggests an uncoupling between grazing and primary productivity.

E. huxleyi is well within the size range of available prey for microzooplankton, which are capable of selectively choosing prey (Burkill et al., 1987; Buskey, 1997). The selection process may occur during detection, prey capture, handling, ingestion, or a combination of all four. The coccoliths surrounding E. huxleyi provide no physical protection from grazing, but are indigestible and may reduce the cell's nutritional value, conceivably making coccolithophorids sub-optimal prey (Young, 1994).

An alternative explanation that would result in grazing selectivity is chemical defense by $E$. huxleyi. Recent studies have demonstrated that many algae are toxic to, or avoided by, micro- and metazooplankton (Admiraal and Venekamp, 1986; Hansen, 1989; Teegarden and Cembella, 1996). Wolfe et al. (1997) showed that certain laboratory strains of E. huxleyi have grazing-activated chemical defense mechanisms. However, grazing deterrence by means of chemical defense shows variability between grazer taxa, and its role in bloom ecology is poorly understood (Turner and Tester, 1997; see Wolfe (2000) for a complete review of microalgal chemical defense ecology).

Regardless of the specific interactions between E. huxleyi and their microzooplankton predators, interactions between microzooplankton and their prey significantly contribute to the structuring of marine plankton communities.

In order to make accurate predictions about the sustainability of the ocean's resources, it is imperative that quantitative microzooplankton herbivory estimates are collected and incorporated into ocean food web models. We report here rates of phytoplankton growth and mortality from microzooplankton grazing in the southeastern Bering Sea. To evaluate the availability of microzooplankton as food for crustacean zooplankton and larval fish, we also quantified microzooplank- ton abundance and biomass. Our primary goal was to compare rates and abundances between bloom and non-bloom regions of the southeastern Bering Sea. Information gained from this research will (1) help determine whether E. huxleyi can be implicated as a causative agent in restructured upper trophic level food web dynamics in the southeastern Bering Sea (Vance et al., 1998), and (2) help build a conceptual framework for the movement of organic carbon through microbial pathways in highly productive, high-latitude ecosystems.

\section{Methods}

\subsection{Methodological considerations}

Microzooplankton are often the same size as their phytoplankton prey; consequently, they cannot be physically separated. For this reason, phytoplankton community growth rates in whole seawater samples are a measure of net growth rate (NGR)

$\mathrm{NGR}=\mu-g$,

where $\mu$ is the intrinsic growth rate, and $g$ is mortality due to grazing.

The dilution method (Landry and Hassett, 1982; Landry, 1993) simultaneously estimates the intrinsic rates of phytoplankton growth and grazing mortality of a microbial population. In principal, a whole seawater sample (WSW) is diluted with particle-free seawater (PFW) from the same source in sequential dilutions. It is presumed that prey growth is density independent, whereas grazing mortality is density-dependent. Therefore, by minimizing encounter rates of prey with their predators, net growth rates will approximate intrinsic growth rates in the highly dilute treatments.

The dilution technique has four restrictive assumptions (Landry, 1993; Neuer and Cowles, 1994): phytoplankton growth rate is unaffected by dilution (i.e. growth must not be density-dependent); microzooplankton density does not change over the course of incubation; microzooplankton grazing rates are linear with respect to prey 
density; and phytoplankton growth is described by the exponential growth equation,

$$
1 / t \ln \left(P_{t} / P_{0}\right)=\mu-g d,
$$

where $P_{t}$ is the chlorophyll a $(\mathrm{Chl} a)$ concentration at time $t\left(\mathrm{~d}^{-1}\right) ; P_{0}$ is the initial $\mathrm{Chl} a$ concentration; $\mu$ and $g$ are the instantaneous coefficients of population growth and grazing related mortality, respectively; and $d$ is the dilution factor.

The disadvantages of the dilution method (Gallegos, 1989) are that the assumptions are difficult to test routinely, growth rates in dilute bottles may be affected by contaminants or enhancements in PFW (Wolfe et al., 2000), and threshold feeding responses at high dilutions may depress grazing rates in dilute samples more than dilution alone (Landry, 1993). In spite of the disadvantages, the dilution method was chosen because it provides simultaneous analysis of different components of a plankton community in a single experiment with minimal disruption to delicate organisms; furthermore, it is the only method that yields an estimate of community grazing rates.

\subsection{Sampling}

All samples were collected on board the R.V. Alpha Helix (cruise 222, 18 July-23 August 1999). Sampling stations selected (Table 1) represented three distinct biogeographical regions with respect to the E. huxleyi bloom: non-bloom (stations 1-4); bloom-fringe (stations 5-11); and bloom (stations 12-18) (Fig. 1). Bloom and bloom-fringe stations were identified based on the extent of visible discoloration of the water. Blooms of E. huxleyi characteristically display high reflectance with only moderate levels of Chl $a$ (Holligan et al., 1993; Garcia-Soto et al., 1995). Stations with high reflectance and chalky appearance were designated bloom, whereas stations with little and no reflectance (i.e. blue water) were designated bloom-fringe and non-bloom, respectively. The biogeographic designations were confirmed by observation of E. huxleyi density using inverted microscopy. Seawater for dilution experiments, measurement of inorganic nutrients, and microzooplankton cell density was collected via a rosette of 5-1 Niskin bottles attached to a CTD. Each bottle was equipped with an external springloaded closing system. Water was collected at depths corresponding to $50 \%$ surface irradiance (depth range 4-30 m; Table 1). Sampling times varied among experiments and were subject to ship availability.

\subsection{Dilution experiments}

Prior to use, all bottles, carboys, silicone tubing, and capsule filters were soaked in $10 \% \mathrm{HCl}$ for $24 \mathrm{~h}$ and subsequently rinsed with reverse osmosis $\mathrm{H}_{2} \mathrm{O}$ and pre-rinsed with filtered seawater. Seawater for dilution experiments was prepared by gently draining the Niskin bottles through silicone tubing enclosed with $200 \mu \mathrm{m}$ Nitex screen (to remove meso- and macrozooplankton) into two 20-1 polycarbonate carboys. One carboy was kept in the dark at $6^{\circ} \mathrm{C}$ until experimental bottles were set up (no longer than $1 \mathrm{~h}$ ), while the second was allowed to gravity filter through a Gelman ${ }^{\circledR}$ pleated capsule filter $(0.2 \mu \mathrm{m}$ pore size $)$ to serve as the PFW.

Whole seawater (WSW) was gently siphoned (the end of the tube submerged) into 1-1 polycarbonate bottles containing premeasured volumes of PFW to achieve target fractions (in duplicate) of whole seawater: $0.1,0.2,0.35$, and 0.6 , along with duplicate 1.0 WSW bottles for each dilution series. In order to satisfy the assumption that phytoplankton growth was unaffected by dilution, and to prevent biased grazing estimates from nutrient regeneration within dilution treatments (Anderson et al., 1991), dissolved inorganic nutrients were added to all experimental bottles to reach target levels of $2 \mu \mathrm{M} \mathrm{PO}_{4}^{3-}$ (added as $\mathrm{KH}_{2} \mathrm{PO}_{4}$ ) and $20 \mu \mathrm{M} \mathrm{NO} \mathrm{NO}_{3}^{-}$(added as $\mathrm{KNO}_{3}$ ). Two additional bottles of $1.0 \mathrm{WSW}$ were incubated without added inorganic nutrients and served as controls for nutrient enrichment effects. Experimental bottles were enclosed in one layer of neutral density screen to simulate $50 \%$ surface irradiance. Experimental bottles were incubated for $24 \mathrm{~h}$ in on-deck incubators supplied with a continuous flow of surface seawater.

Initial chlorophyll samples were taken at each experimental location from 20-1 WSW carboys. 
Table 1

Stations, biogeographic region, location, date, local time, sampling depth, and water temperature for dilution experiments

\begin{tabular}{|c|c|c|c|c|c|c|c|}
\hline Station & BGR & Latitude & Longitude & Date & Time (Local) & Depth (m) & Temp $\left({ }^{\circ} \mathrm{C}\right)$ \\
\hline 1 & NB & $55^{\circ} 17.38 \mathrm{~N}$ & $164^{\circ} 12.56 \mathrm{~W}$ & 29 July 1999 & 1600 & 6 & 6.5 \\
\hline 2 & NB & $55^{\circ} 41.66 \mathrm{~N}$ & $164^{\circ} 33.10 \mathrm{~W}$ & 27 July 1999 & 1240 & 8 & 6.0 \\
\hline 3 & NB & $56^{\circ} 52.48 \mathrm{~N}$ & $159^{\circ} 99.24 \mathrm{~W}$ & 1 Aug 1999 & 1230 & 11 & 10.5 \\
\hline 4 & NB & $56^{\circ} 86.38 \mathrm{~N}$ & $160^{\circ} 52.89 \mathrm{~W}$ & 31 July 1999 & 1320 & 9 & 6.8 \\
\hline 5 & $\mathrm{BF}$ & $57^{\circ} 13.20 \mathrm{~N}$ & $164^{\circ} 08.51 \mathrm{~W}$ & 23 July 1999 & 0940 & 5 & 7.0 \\
\hline 6 & $\mathrm{BF}$ & $56^{\circ} 20.79 \mathrm{~N}$ & $164^{\circ} 33.78 \mathrm{~W}$ & 21 July 1999 & 1800 & 30 & 1.5 \\
\hline 7 & $\mathrm{BF}$ & $56^{\circ} 81.54 \mathrm{~N}$ & $164^{\circ} 01.12 \mathrm{~W}$ & 8 Aug 1999 & 1130 & 7 & 7.9 \\
\hline 8 & $\mathrm{BF}$ & $57^{\circ} 13.16 \mathrm{~N}$ & $171^{\circ} 21.88 \mathrm{~W}$ & 16 Aug 1999 & 2114 & 10 & 8.4 \\
\hline 9 & $\mathrm{BF}$ & $56^{\circ} 46.12 \mathrm{~N}$ & $169^{\circ} 57.95 \mathrm{~W}$ & 17 Aug 1999 & 0530 & 10 & 6.4 \\
\hline 10 & $\mathrm{BF}$ & $57^{\circ} 27.25 \mathrm{~N}$ & $169^{\circ} 39.45 \mathrm{~W}$ & 16 Aug 1999 & 0029 & 6 & 8.3 \\
\hline 11 & $\mathrm{BF}$ & $57^{\circ} 77.16 \mathrm{~N}$ & $163^{\circ} 04.07 \mathrm{~W}$ & 7 Aug 1999 & 1505 & 5 & 6.3 \\
\hline 12 & $\mathrm{~B}$ & $57^{\circ} 45.78 \mathrm{~N}$ & $163^{\circ} 37.59 \mathrm{~W}$ & 5 Aug 1999 & 2226 & 7 & 6.4 \\
\hline 13 & B & $57^{\circ} 30.29 \mathrm{~N}$ & $163^{\circ} 53.94 \mathrm{~W}$ & 6 Aug 1999 & 1500 & 5 & 7.6 \\
\hline 14 & B & $57^{\circ} 18.83 \mathrm{~N}$ & $163^{\circ} 66.38 \mathrm{~W}$ & 9 Aug 1999 & 0100 & 6 & 8.0 \\
\hline 15 & B & $59^{\circ} 38.38 \mathrm{~N}$ & $167^{\circ} 13.86 \mathrm{~W}$ & 13 Aug 1999 & 0856 & 4 & 7.2 \\
\hline 16 & B & $59^{\circ} 10.35 \mathrm{~N}$ & $167^{\circ} 44.96 \mathrm{~W}$ & 11 Aug 1999 & 1159 & 7 & 5.8 \\
\hline 17 & B & $58^{\circ} 44.73 \mathrm{~N}$ & $168^{\circ} 13.66 \mathrm{~W}$ & 12 Aug 1999 & 1541 & 5 & 6.4 \\
\hline 18 & B & $58^{\circ} 21.67 \mathrm{~N}$ & $168^{\circ} 39.20 \mathrm{~W}$ & 11 Aug 1999 & 2030 & 7 & 6.0 \\
\hline
\end{tabular}

BGR: biogeographic region. NB: non-bloom; BF: bloom-fringe; B: bloom.

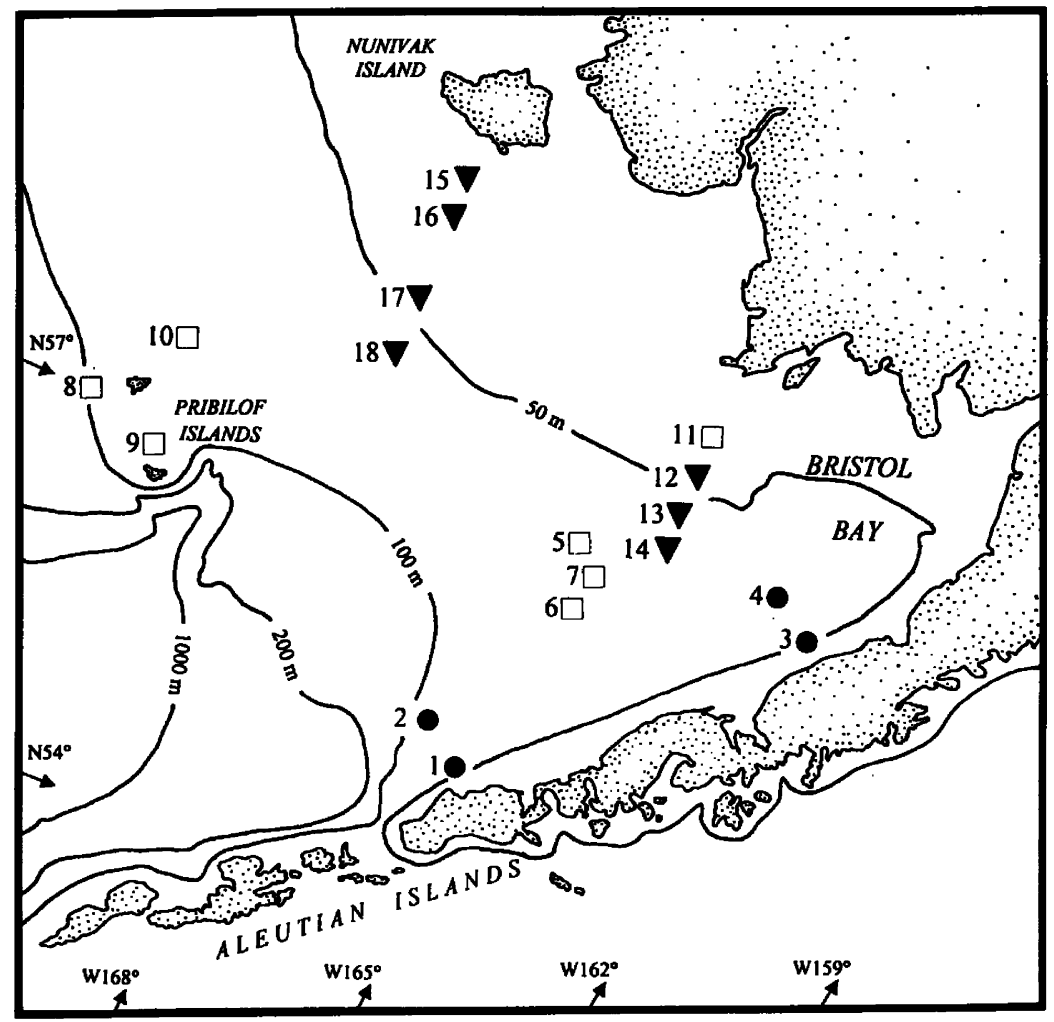

Fig. 1. Map of the southeastern Bering Sea showing experimental station locations. ( $)$ non-bloom; $(\square)$ bloom-fringe; ( $\mathbf{\nabla})$ bloom. 
Volumes varied (60-500 ml) depending on ambient Chl $a$ concentrations. Quadruplicate samples for total Chl $a$ were filtered through Poretics ${ }^{\circledR}$ GF-75 filters $(0.7 \mu \mathrm{m}$ effective pore size $)$ at $\sim 100 \mathrm{~mm} \mathrm{Hg}$ vacuum pressure, while quadruplicate samples for $>10 \mu \mathrm{m}$ Chl $a$ were filtered through Poretics ${ }^{\circledR}$ polycarbonate filters $(10 \mu \mathrm{m}$ pore size). Filters were folded in aluminum foil, placed in cryovials, and subsequently frozen in liquid nitrogen until processing. Two types of preserved samples were taken from the 20-1 WSW carboy for cell enumeration and identification. Duplicate samples $(250 \mathrm{ml})$ for microzooplankton enumeration were preserved in $10 \%$ (final concentration) acid Lugol's, while duplicate $15-\mathrm{ml}$ samples for $E$. huxleyi enumeration were preserved in alkaline Lugol's (to prevent coccolith dissolution).

\subsection{Size fractionated chlorophyll}

Filtered cells on GF-75 and $10 \mu \mathrm{m}$ pore-size polycarbonate filters were placed in test tubes containing $6 \mathrm{ml}$ of $90 \%$ aqueous acetone. Extraction took place in the dark at $-20^{\circ} \mathrm{C}$ for $24 \mathrm{~h}$. Chl $a$ and phaeopigments were analyzed by a Turner Model 112 fluorometer following the methods of Parsons et al. (1984). Chl $a$ concentrations were calculated according to Lorenzen (1966). Chl $a$ in the $<10 \mu \mathrm{m}$ size fraction was estimated from the difference between total (GF-75) and $>10 \mu \mathrm{m}$ concentrations. Replicate 10-ml WSW samples preserved in alkaline Lugol's were settled in inverted microscope counting chambers for $24 \mathrm{~h}$. Phytoplankton community composition was qualitatively evaluated at $400 \times$ using inverted microscopy.

\subsection{Nutrient analysis}

Samples from the 20-1 PFW carboy were taken to determine concentrations $(\mu \mathrm{M})$ of $\mathrm{PO}_{4}^{3-}$, $\mathrm{Si}(\mathrm{OH})_{4}, \mathrm{NO}_{3}^{-}$, and $\mathrm{NH}_{4}^{+}$. Samples were analyzed with an Alpkem autoanalyzer on board ship using the methods of Whitledge et al. (1981).

\subsection{Phytoplankton specific growth and microzooplankton grazing}

Each incubation bottle in the dilution series yields an independent estimate of the NGR of the phytoplankton,

$\operatorname{NGR}\left(\mathrm{d}^{-1}\right)=1 / t \ln \left(P_{t} / P_{0}\right)$.

The rates of phytoplankton growth and grazing mortality for phytoplankton cells in total, $>10 \mu \mathrm{m}$, and $<10 \mu \mathrm{m}$ size fractions were estimated by Model I linear regression of NGR verses dilution factor (i.e. grazer density) (Landry, 1993). The ordinate intercept of the regression is the intrinsic rate of phytoplankton growth $\left(\mu, \mathrm{d}^{-1}\right)$ in the absence of grazing, and the negative slope of the regression is the rate of mortality $\left(g, \mathrm{~d}^{-1}\right)$ attributable to microzooplankton grazing. In regions of high phytoplankton biomass, prey availability may be saturating to grazers even in some diluted treatments. As a result, $\mu$ and $g$ are underestimated (Gallegos, 1989). At stations where grazing saturation occurred, $\mu$ was estimated with piecewise regression (Rivkin et al., $1999)$ by analyzing the three highest dilutions $(0.1$, 0.2 , and 0.35 ), whereas $g$ was calculated by the rearrangement of Eq. (1) into

$g=\mu-\mathrm{NGR}_{1.0+}$,

where $\mathrm{NGR}_{1.0+}$ is the net growth in nutrientenriched 1.0 WSW bottles. Phytoplankton growth rate in control bottles without added inorganic nutrients was calculated as

$\mu_{\text {(-nutrients) }}=\mathrm{NGR}_{1.0-}+g$,

where $\mathrm{NGR}_{1.0-}$ is the net growth rate in unenriched 1.0 WSW bottles and $g$ is the estimated grazing rate from the corresponding enriched dilution series.

\subsection{Microzooplankton abundance and biomass}

Replicate WSW acid Lugol's-preserved samples from each experimental station were settled in inverted microscope counting chambers for $24 \mathrm{~h}$. Settled volumes varied but were determined to allow for the enumeration and digitization of $\geqslant 200$ cells. Acid Lugol's was chosen as the fixative because it preserves the greatest number of ciliates as compared with other fixatives (Stoecker et al., 1995). Unfortunately, preservation in acid Lugol's does not allow chlorophyll autofluorescence to be maintained. Because it was not possible to 
determine unequivocally whether cells were autotrophic or heterotrophic, all ciliates and dinoflagellates $>10 \mu \mathrm{m}$ were included in abundance, biomass, and volume estimates. However, strictly autotrophic species were rare, and many, if not most, autotrophic dinoflagellates are capable of phagocytic activity (Steidinger and Tangen, 1996; Stoecker, 1999).

Cells in duplicate samples were enumerated and measured using a computer-aided digitizer (Roff and Hopcroft, 1986). Biovolume was converted

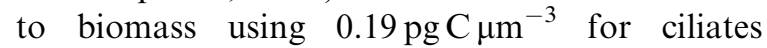
(Putt and Stoecker, 1989) and $0.14 \mathrm{pg} \mathrm{C} \mu \mathrm{m}^{-3}$ for dinoflagellates (Lessard, 1991). Metazoan larvae were encountered in a few samples, but were extremely rare. Thus, they were excluded from our estimates.

\subsection{Statistical analysis}

Differences among biogeographic regions for total, $>10 \mu \mathrm{m}$, and $<10 \mu \mathrm{m}$ Chl $a$, rates of phytoplankton growth and grazing mortality (pooled regressions), as well as microzooplankton abundance and biomass were analyzed by one-way ANOVA (SPSS software). The assumption of homogeneous variances was not met in all cases ( $>10 \mu \mathrm{m} \mathrm{Chl} a$, ciliate, and heterotrophic dinoflagellate biomass). When this occurred, logarithmic transformations of data were performed. $A$ posteriori multiple comparisons of ranked means were performed using Tukey's HSD test (Chew, 1976). Paired $t$-tests were used to test for differences between nutrient enriched and unenriched phytoplankton growth rates. Pearson correlations were used to test whether ambient nutrient concentrations correlated with phytoplankton biomass, and if phytoplankton biomass correlated with microzooplankton grazing rates.

\section{Results}

\subsection{Size-fractionated Chl a}

Total phytoplankton biomass, estimated from Chl $a$, significantly increased $(F=7.93, P=0.004)$ from non-bloom and bloom-fringe stations (1-11) to the bloom stations (12-18) (Fig. 2). Concentrations ranged from 0.36 to $4.45 \mu \mathrm{g}$ Chl $a 1^{-1}$. Surprisingly, despite the discoloration of the water from the increased presence of E. huxleyi, much of the increase in phytoplankton biomass at bloom stations was associated with cells $>10 \mu \mathrm{m}$. Chl $a$ concentrations in the $>10 \mu \mathrm{m}$ size fraction were significantly lower $(F=20.37, P \ll 0.001)$ on average at non-bloom and bloom-fringe stations (avg. $0.20 \mu \mathrm{g} 1^{-1}, n=11$ ) than at bloom stations (avg. $1.60 \mu \mathrm{gl}^{-1}, n=7$ ) (Fig. 2). Much of this difference appeared to be a result of high abundance of the diatom Nitzschia spp. at many bloom stations.

Phytoplankton biomass in cells $<10 \mu \mathrm{m}$ tended to be slightly higher at bloom stations, but differences were not statistically significant $(F=0.56, P=0.58) \quad$ (Fig. 2). Average $<10 \mu \mathrm{m}$ Chl $a$ concentrations for the non-bloom, bloomfringe, and bloom stations were $0.55(n=4), 0.77$ $(n=7)$, and $0.87(n=7) \mu \mathrm{g} \mathrm{Chl} a 1^{-1}$, respectively. Although biomass did not differ significantly among regions, species composition in the $<10 \mu \mathrm{m}$ community shifted from a mixed assemblage at the non-bloom stations to an assemblage dominated by E. huxleyi at the bloom-fringe and bloom stations (Table 2). This shift in species diversity was also evident in the visual discoloration of the water.

\subsection{Nutrient concentrations}

Inorganic nutrient concentrations showed extreme spatial heterogeneity (Fig. 3): $\mathrm{NO}_{3}^{-}$ranged from 0.23 to $5.95 \mu \mathrm{M} ; \mathrm{PO}_{4}^{3-}$ ranged from undetectable to $0.89 \mu \mathrm{M} ; \mathrm{Si}(\mathrm{OH})_{4}$ ranged from 0.07 to $27.40 \mu \mathrm{M}$; and $\mathrm{NH}_{4}^{+}$ranged from 0.13 to $6.39 \mu \mathrm{M}$. Overall, near-surface nutrient levels were low during this study, and the highest values appear to represent isolated patches of nutrient enrichment. Only four stations (1, 2, 8, and 9) showed concentrations higher than $5 \mu \mathrm{M}$ for $\mathrm{Si}(\mathrm{OH})_{4}$, and only two locations $(1,9)$ registered concentrations greater than $1 \mu \mathrm{M} \mathrm{NO} \mathrm{NO}_{3}^{-}$. Conversely, only one station (3) registered a concentration less than $1 \mu \mathrm{M} \mathrm{NH} \mathrm{NH}_{4}^{+}$. No significant correlation existed between phytoplankton biomass and surface nutrient concentrations $\left(\mathrm{NO}_{3}^{-}, \mathrm{PO}_{4}^{3-}, \mathrm{Si}(\mathrm{OH})_{4}\right.$, and $\mathrm{NH}_{4}^{+} ; P>0.1$ in all cases). 

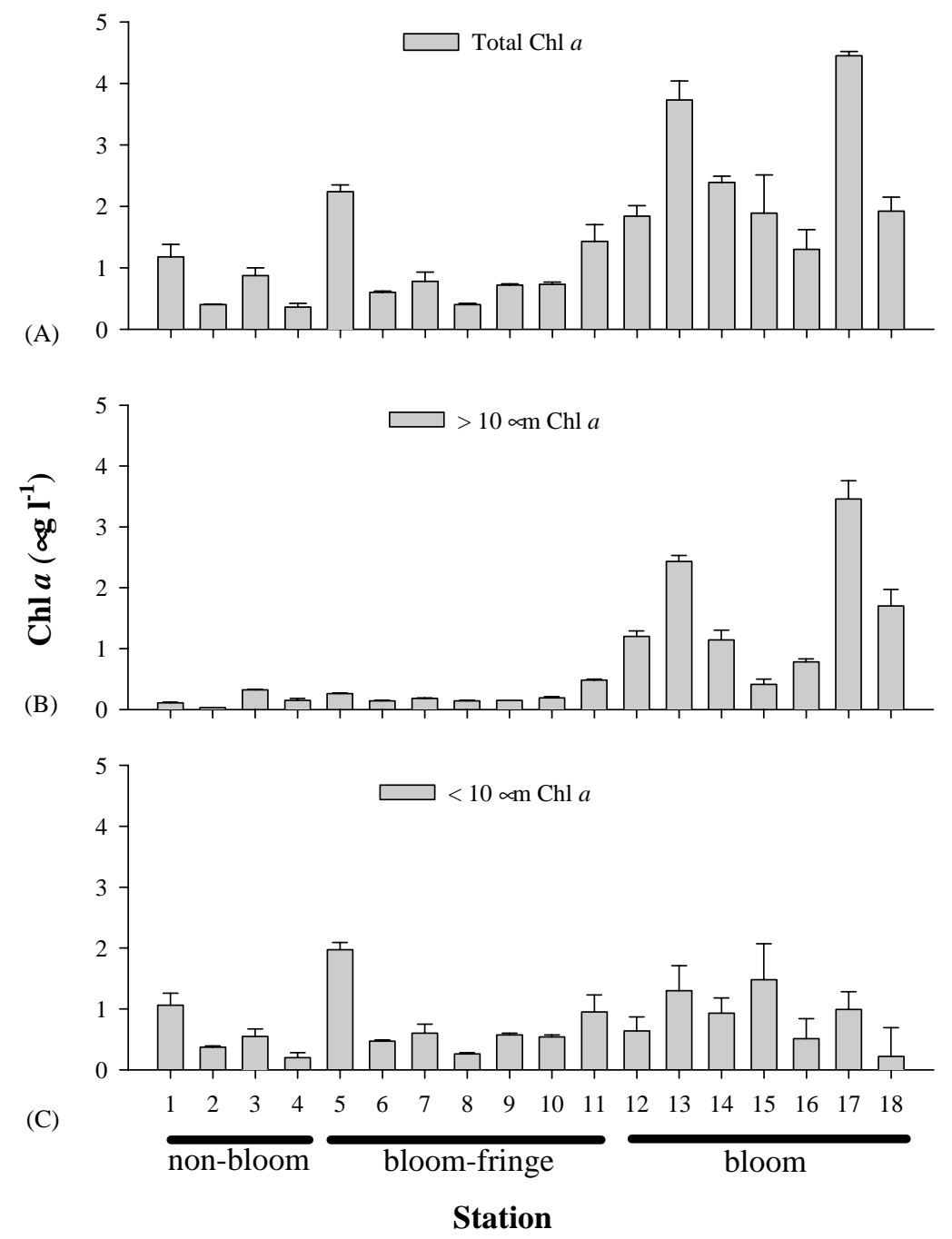

Fig. 2. Chl $a$ concentrations $\left(\mu \mathrm{gl}^{-1}\right.$ ) for (A) total, (B) $>10 \mu \mathrm{m}$, and $(\mathrm{C})<10 \mu \mathrm{m}$ cells. Values are means $(n=4)$. Total and $>10 \mu \mathrm{m}$ $\mathrm{Chl} a$ concentrations are based on direct measurements, while $<10 \mu \mathrm{m}$ concentrations are calculated by difference. Error bars represent upper $95 \%$ confidence intervals.

\subsection{Phytoplankton growth and microzooplankton herbivory}

Nutrient-enhanced phytoplankton growth rates ranged widely across all experimental locations (Table 3). Total phytoplankton growth rates ranged from 0.28 to $1.10 \mathrm{~d}^{-1}$. Phytoplankton growth rates in the $>10 \mu \mathrm{m}$ size fraction ranged from -0.40 to $1.13 \mathrm{~d}^{-1}$, whereas growth rates for the $<10 \mu \mathrm{m}$ size fraction ranged from 0.29 to $1.12 \mathrm{~d}^{-1}$. No significant differences existed in phytoplankton growth amongst the three biogeographical regions for total $(F=2.46, P=0.119)$ and $<10 \mu \mathrm{m}$ Chl $a(F=0.78, P=0.473)$; however, growth rates in the $>10 \mu \mathrm{m} \mathrm{Chl} \mathrm{a} \mathrm{size}$ fraction were significantly lower at bloom stations than at non-bloom and bloom-fringe stations $(F=6.26, P=0.011)$. 
Table 2

Percent contribution (\%) of $>10 \mu \mathrm{m}$ and $<10 \mu \mathrm{m} \mathrm{Chl} a$ to total Chl $a$ and dominant phytoplankton taxa for dilution experiment stations

\begin{tabular}{|c|c|c|c|c|}
\hline \multirow[t]{2}{*}{ Station } & \multirow[t]{2}{*}{ BGR } & \multicolumn{2}{|c|}{$\%$ Total Chl $a$} & \multirow[t]{2}{*}{ Phytoplankton assemblage } \\
\hline & & $>10 \mu \mathrm{m}$ & $<10 \mu \mathrm{m}$ & \\
\hline 1 & NB & 10 & 90 & $\begin{array}{l}\text { Many cryptomonads, chlorophytes, other small unidentified flagellates, small dinos } \\
(<10 \mu \mathrm{m}) \text {, no diatoms }\end{array}$ \\
\hline 2 & NB & 7 & 93 & Many cryptomonads, chlorophytes, other coccoid flagellates, no diatoms \\
\hline 3 & NB & 37 & 63 & $\begin{array}{l}\text { Mixed assemblage of small flagellates }(<7 \mu \mathrm{m}) \text {, few diatoms (Nitzschia, Neurosigma, } \\
\text { Chaetoceros) }\end{array}$ \\
\hline 4 & NB & 44 & 56 & Few cryptomonads and chlorophytes, few diatoms (Leptocylindrus, Nitzschia) \\
\hline 5 & $\mathrm{BF}$ & 12 & 88 & E. huxleyi, cryptomonads, small round dinos $(<10 \mu \mathrm{m})$, no diatoms \\
\hline 6 & $\mathrm{BF}$ & 22 & 78 & Many cryptomonads, Nitzschia, few E. huxleyi \\
\hline 7 & $\mathrm{BF}$ & 23 & 77 & E. huxleyi, cryptomonads, cryptophytes, some Nitzschia \\
\hline 8 & $\mathrm{BF}$ & 35 & 65 & Small flagellates $(\leqslant 5 \mu \mathrm{m})$, diatom fragments \\
\hline 9 & $\mathrm{BF}$ & 21 & 79 & $\begin{array}{l}\text { Many cryptomonads, few E. huxleyi, Rhizosolenia, Chaetoceros fragments, other } \\
\text { small coccoid flagellates }\end{array}$ \\
\hline 10 & $\mathrm{BF}$ & 26 & 74 & Large Nitzschia $(>50 \mu \mathrm{m})$, Leptocylindrus, few E. huxleyi, small dinos $(<10 \mu \mathrm{m})$ \\
\hline 11 & $\mathrm{BF}$ & 34 & 66 & Mixed diatoms (Navicula, Coscinodiscus, Paralia), few E. huxleyi and cryptomonads \\
\hline 12 & $\mathrm{~B}$ & 65 & 35 & Very many Nitzschia and E. huxleyi, few Leptocylindrus, few Ceratium $(\cong 260 \mu \mathrm{m})$ \\
\hline 13 & $\mathrm{~B}$ & 65 & 35 & Numerical dominance by E. huxleyi, very few cryptomonads and Leptocylindrus \\
\hline 14 & B & 61 & 39 & Dominance by $E$. huxleyi and Nitzschia, very few cryptomonads \\
\hline 15 & $\mathrm{~B}$ & 21 & 78 & $\begin{array}{l}\text { Very many E. huxleyi, mixed diatoms (Nitzschia, Chaetoceros, Navicula, } \\
\text { Pleurosigma) }\end{array}$ \\
\hline 16 & $\mathrm{~B}$ & 61 & 39 & $\begin{array}{l}\text { E. huxleyi, Nitzschia, small flagellates }(\leqslant 5 \mu \mathrm{m}) \text {, mixed assemblage of diatom } \\
\text { fragments }\end{array}$ \\
\hline 17 & $\mathrm{~B}$ & 78 & 22 & Dominance by $E$. huxleyi and large Nitzschia $(200 \times 5 \mu \mathrm{m})$ \\
\hline 18 & $\mathrm{~B}$ & 89 & 11 & E. huxleyi, many Nitzschia, Leptocylindrus, Thalassiosira \\
\hline
\end{tabular}

BGR: biogeographic region. NB: non-bloom; BF: bloom-fringe; B: bloom. Phytoplankton community composition was qualitatively described at $400 \times$ using inverted microscopy.

In order to satisfy the assumption that dilution does not affect phytoplankton growth, inorganic nutrients were added to experimental bottles. Because addition of nutrients may promote phytoplankton growth and misrepresent in situ intrinsic growth rates, experimental bottles without added nutrients served as controls. Nutrient enrichment had no significant effect on phytoplankton growth for the $<10 \mu \mathrm{m}$ size fraction indicating that, in general, phytoplankton growth rates for small cells in the Bering Sea during this study were not nutrient limited (Paired $t$-test, $P=0.946)$. Growth rates in cells $>10 \mu \mathrm{m}$, however, were nutrient limited during this study (Paired $t$-test, $P=0.010$ ), likely a result of the low surface concentrations of $\mathrm{NO}_{3}^{-}$. Interestingly, bottles with nutrient enrichment occasionally showed lower phytoplankton growth rates than unenriched bottles (Table 3). This was especially true for the $<10 \mu \mathrm{m}$ size fraction, which showed no nutrient limitation.

Microzooplankton grazing rates varied among location and Chl a size fraction (Table 3). Microzooplankton grazing rates on total $\mathrm{Chl} a$ ranged from 0.11 to $1.09 \mathrm{~d}^{-1}$. Multiple comparison of pooled regressions showed no significant difference in grazing on total Chl $a$ amongst locations $(F=2.28, P=0.136)$. However, grazing rates on total $\mathrm{Chl} a$ exceeded phytoplankton growth rates at 3 of the 4 non-bloom stations (Fig. 4a). In contrast, at the bloom-fringe and bloom stations, growth equaled or exceeded grazing at 11 of the 14 stations.

Grazing on phytoplankton cells $>10 \mu \mathrm{m}$ showed no significant difference amongst locations $(F=0.75, P=0.490)$. Grazing rates ranged from 0.19 to $1.14 \mathrm{~d}^{-1}$, and were exceeded by phytoplankton growth at all 4 non-bloom stations, as 

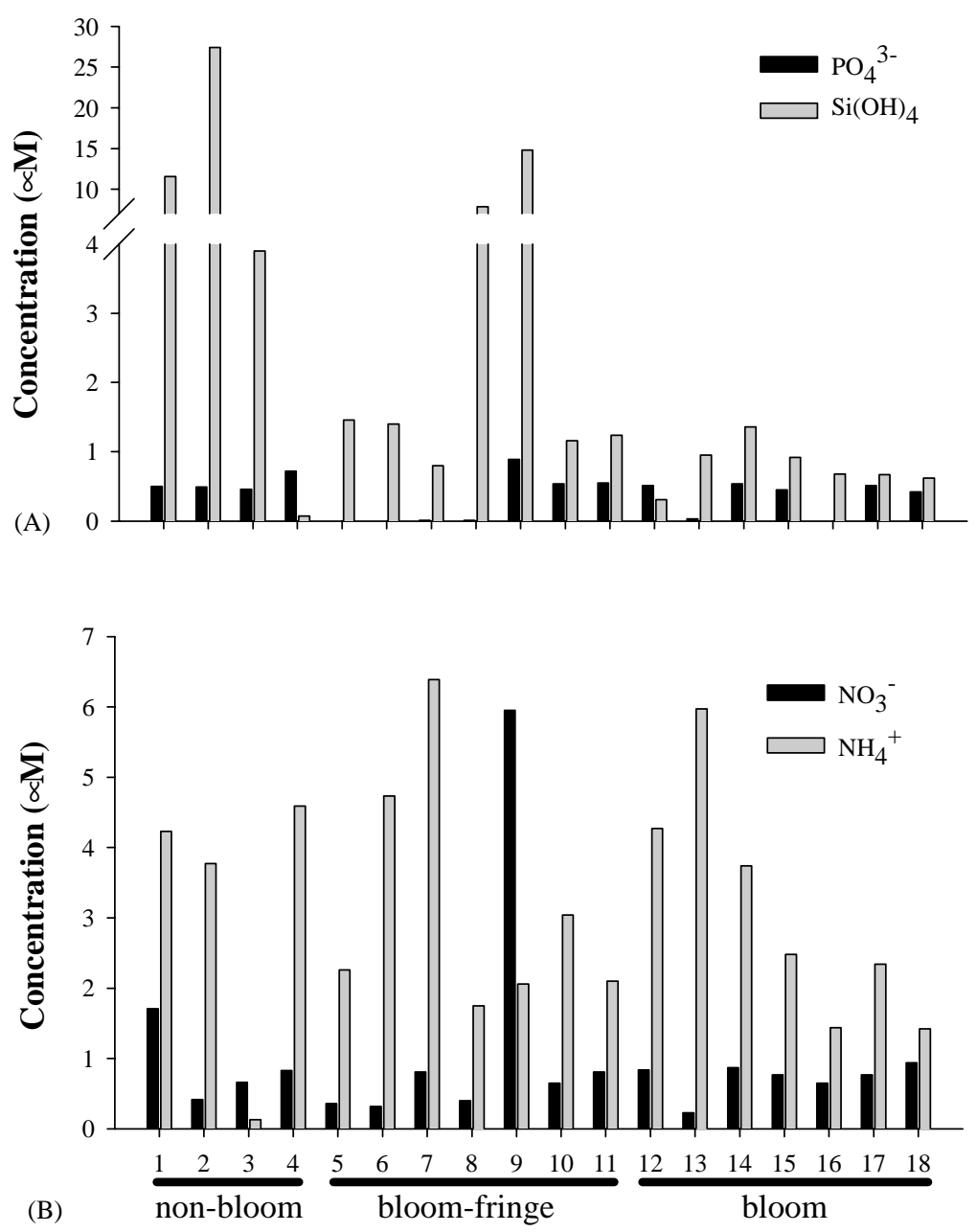

Station

Fig. 3. Inorganic nutrient concentrations $(\mu \mathrm{M})$ for $(\mathrm{A}) \mathrm{PO}_{4}^{3-}$ and $\mathrm{Si}(\mathrm{OH})_{4}$, and $(\mathrm{B}) \mathrm{NO}_{3}^{-}$and $\mathrm{NH}_{4}^{+}$for all dilution experiments. See Table 1 for depths of water collection. Note changing $Y$ axis for each graph. Concentrations of $\mathrm{PO}_{4}^{3-}$ were undetectable when bars are not visible.

well as at 4 of the 7 bloom-fringe stations (Fig. 4b). Unlike the results observed for the total phytoplankton assemblage, grazing on the $>10 \mu \mathrm{m}$ cells exceeded phytoplankton growth at 6 of the 7 bloom stations.

Microzooplankton grazing rates on $\mathrm{Chl} a$ $<10 \mu \mathrm{m}$ ranged from 0.02 to $1.07 \mathrm{~d}^{-1}$ and showed a pattern of decreased grazing relative to phytoplankton growth with increasing proximity to the bloom (Fig. 4c). Although no differences were observed in $<10 \mu \mathrm{m}$ Chl $a$ biomass among stations, grazing rates on $<10 \mu \mathrm{m}$ Chl $a$ were significantly lower at bloom than non-bloom locations $(F=4.76, P=0.025)$.

Many studies have observed that a tight coupling exists between rates of microzooplankton grazing and small phytoplankton growth (summarized by Sherr and Sherr, 1994). In our study, however, rates of phytoplankton growth were met and, at several locations, were exceeded by 
Table 3

Rates of phytoplankton nutrient-enhanced growth $\left(\mu, \mathrm{d}^{-1}\right)$, grazing mortality $\left(g, \mathrm{~d}^{-1}\right)$, and $g: \mu$ from total Chl $a$ regressions for all dilution experiments

\begin{tabular}{|c|c|c|c|c|c|c|c|c|c|c|}
\hline \multirow[t]{2}{*}{ Station } & \multirow[t]{2}{*}{ BGR } & \multicolumn{3}{|l|}{ Growth } & \multicolumn{3}{|l|}{ Grazing } & \multicolumn{3}{|l|}{$g: \mu$} \\
\hline & & Total & $>10 \mu \mathrm{m}$ & $<10 \mu \mathrm{m}$ & Total & $>10 \mu \mathrm{m}$ & $<10 \mu \mathrm{m}$ & Total & $>10 \mu \mathrm{m}$ & $<10 \mu \mathrm{m}$ \\
\hline 1 & NB & $\begin{array}{l}0.72 \pm 0.39^{\mathrm{a}} \\
(0.56)\end{array}$ & $\begin{array}{l}0.97 \pm 0.23^{\mathrm{a}} \\
(0.95)\end{array}$ & $\begin{array}{l}0.68 \pm 0.43^{\mathrm{a}} \\
(0.48)\end{array}$ & $1.02 \pm 0.14$ & $0.67 \pm 0.14$ & $1.06 \pm 0.19$ & 1.41 & 0.69 & 1.56 \\
\hline 2 & NB & $\begin{array}{l}0.42 \pm 0.05 \\
(0.77)\end{array}$ & $\begin{array}{l}0.71 \pm 0.07 \\
(0.64)\end{array}$ & $\begin{array}{l}0.40 \pm 0.05 \\
(0.83)\end{array}$ & $0.70 \pm 0.09$ & $0.19 \pm 0.13$ & $0.78 \pm 0.10$ & 1.67 & 0.27 & 1.95 \\
\hline 3 & NB & $\begin{array}{l}0.38 \pm 0.08 \\
(0.38)\end{array}$ & $\begin{array}{l}0.61 \pm 0.13^{\mathrm{a}} \\
(0.52)\end{array}$ & $\begin{array}{l}0.37 \pm 0.08 \\
(0.42)\end{array}$ & $0.60 \pm 0.16$ & $0.33 \pm 0.01$ & $0.88 \pm 0.14$ & 1.58 & 0.54 & 2.38 \\
\hline 4 & NB & $\begin{array}{l}0.84 \pm 0.22^{\mathrm{a}} \\
(0.71)\end{array}$ & $\begin{array}{l}1.13 \pm 0.11^{\mathrm{a}} \\
(1.04)\end{array}$ & $\begin{array}{l}0.63 \pm 0.23^{\mathrm{a}} \\
(0.45)\end{array}$ & $0.26 \pm 0.08$ & $0.48 \pm 0.14$ & $0.10 \pm 0.04$ & 0.31 & 0.42 & 0.16 \\
\hline 5 & $\mathrm{BF}$ & $\begin{array}{l}0.44 \pm 0.08 \\
(0.24)\end{array}$ & $\begin{array}{l}0.88 \pm 0.13^{\mathrm{a}} \\
(0.74)\end{array}$ & $\begin{array}{l}0.42 \pm 0.09 \\
(0.19)\end{array}$ & $0.25 \pm 0.16$ & $0.66 \pm 0.14$ & $0.21 \pm 0.16$ & 0.57 & 0.75 & 0.50 \\
\hline 6 & $\mathrm{BF}$ & $\begin{array}{l}1.10 \pm 0.13 \\
(1.02)\end{array}$ & $\begin{array}{l}0.55 \pm 0.09 \\
(0.56)\end{array}$ & $\begin{array}{l}1.11 \pm 0.24 \\
(1.13)\end{array}$ & $0.11 \pm 0.14$ & $0.24 \pm 0.16$ & $0.10 \pm 0.44$ & 0.10 & 0.44 & 0.09 \\
\hline 7 & $\mathrm{BF}$ & $\begin{array}{l}0.68 \pm 0.08 \\
(0.57)\end{array}$ & $\begin{array}{l}0.80 \pm 0.10 \\
(0.49)\end{array}$ & $\begin{array}{l}0.65 \pm 0.09 \\
(0.58)\end{array}$ & $0.35 \pm 0.14$ & $0.59 \pm 0.18$ & $0.28 \pm 0.16$ & 0.51 & 0.74 & 0.43 \\
\hline 8 & $\mathrm{BF}$ & $\begin{array}{l}0.34 \pm 0.07 \\
(0.56)\end{array}$ & $\begin{array}{l}0.40 \pm 0.09 \\
(0.36)\end{array}$ & $\begin{array}{l}0.29 \pm 0.08 \\
(0.66)\end{array}$ & $0.53 \pm 0.11$ & $0.45 \pm 0.16$ & $0.58 \pm 0.16$ & 1.56 & 1.13 & 2.00 \\
\hline 9 & $\mathrm{BF}$ & $\begin{array}{l}0.66 \pm 0.08^{\mathrm{a}} \\
(0.60)\end{array}$ & $\begin{array}{l}0.95 \pm 0.10 \\
(0.92)\end{array}$ & $\begin{array}{l}0.41 \pm 0.12^{\mathrm{a}} \\
(0.35)\end{array}$ & $0.23 \pm 0.01$ & $0.41 \pm 0.09$ & $0.15 \pm 0.08$ & 0.35 & 0.43 & 0.37 \\
\hline 10 & $\mathrm{BF}$ & $\begin{array}{l}0.54 \pm 0.09 \\
(0.94)\end{array}$ & $\begin{array}{l}1.13 \pm 0.08 \\
(0.98)\end{array}$ & $\begin{array}{l}0.44 \pm 0.12 \\
(0.69)\end{array}$ & $1.09 \pm 0.02$ & $1.14 \pm 0.10$ & $1.07 \pm 0.02$ & 2.02 & 1.01 & 2.43 \\
\hline 11 & $\mathrm{BF}$ & $\begin{array}{l}0.58 \pm 0.21^{\mathrm{a}} \\
(0.60)\end{array}$ & $\begin{array}{l}0.50 \pm 0.21^{\mathrm{a}} \\
(0.75)\end{array}$ & $\begin{array}{l}0.61 \pm 0.35^{\mathrm{a}} \\
(0.55)\end{array}$ & $0.53 \pm 0.00$ & $0.67 \pm 0.03$ & $0.49 \pm 0.01$ & 0.91 & 1.34 & 0.80 \\
\hline 12 & B & $\begin{array}{l}0.36 \pm 0.07 \\
(0.22)\end{array}$ & $\begin{array}{l}0.32 \pm 0.12 \\
(0.20)\end{array}$ & $\begin{array}{l}0.56 \pm 0.16 \\
(0.47)\end{array}$ & $0.16 \pm 0.05$ & $0.38 \pm 0.20$ & $0.04 \pm 0.14$ & 0.44 & 1.19 & 0.07 \\
\hline 13 & B & $\begin{array}{l}0.30 \pm 0.19 \\
(0.31)\end{array}$ & $\begin{array}{l}0.13 \pm 0.44 \\
(0.21)\end{array}$ & $\begin{array}{l}0.55 \pm 0.51 \\
(0.38)\end{array}$ & $0.33 \pm 0.33$ & $0.31 \pm 0.16$ & $0.25 \pm 0.25$ & 1.10 & 2.38 & 0.45 \\
\hline 14 & B & $\begin{array}{l}0.61 \pm 0.06^{\mathrm{a}} \\
(0.37)\end{array}$ & $\begin{array}{l}0.37 \pm 0.09 \\
(0.22)\end{array}$ & $\begin{array}{l}0.78 \pm 0.15 \\
(0.56)\end{array}$ & $0.41 \pm 0.01$ & $0.70 \pm 0.07$ & $0.16 \pm 0.03$ & 0.67 & 1.89 & 0.21 \\
\hline 15 & B & $\begin{array}{l}0.48 \pm 0.09 \\
(0.44)\end{array}$ & $\begin{array}{l}0.84 \pm 0.28^{\mathrm{a}} \\
(0.76)\end{array}$ & $\begin{array}{l}0.45 \pm 0.09 \\
(0.38)\end{array}$ & $0.32 \pm 0.16$ & $0.73 \pm 0.15$ & $0.24 \pm 0.16$ & 0.67 & 0.87 & 0.53 \\
\hline 16 & B & $\begin{array}{l}0.40 \pm 0.32 \\
(0.52)\end{array}$ & $\begin{array}{l}0.42 \pm 0.08 \\
(0.25)\end{array}$ & $\begin{array}{l}0.38 \pm 0.29 \\
(0.70)\end{array}$ & $0.48 \pm 0.04$ & $0.67 \pm 0.14$ & $0.25 \pm 0.18$ & 1.20 & 1.60 & 0.66 \\
\hline 17 & B & $\begin{array}{l}0.28 \pm 0.10 \\
(0.18)\end{array}$ & $\begin{array}{l}-0.40 \pm 0.23^{\mathrm{a}} \\
(-0.59)\end{array}$ & $\begin{array}{l}1.12 \pm 0.20 \\
(1.12)\end{array}$ & $0.22 \pm 0.16$ & $0.35 \pm 0.06$ & $0.05 \pm 0.15$ & 0.79 & b & 0.04 \\
\hline 18 & B & $\begin{array}{l}0.36 \pm 0.06 \\
(-0.05)\end{array}$ & $\begin{array}{l}0.15 \pm 0.08 \\
(-0.05)\end{array}$ & $\begin{array}{l}1.09 \pm 0.19 \\
(1.06)\end{array}$ & $0.15 \pm 0.03$ & $0.44 \pm 0.15$ & $0.02 \pm 0.30$ & 0.42 & 2.93 & 0.02 \\
\hline
\end{tabular}

\footnotetext{
${ }^{a}$ Growth estimates in which grazing saturation occurred. Numbers in parenthesis are phytoplankton growth rates without added nutrients. BGR: biogeographic region. NB: non-bloom; BF: bloom-fringe; B: bloom. Total and >10 $\mu \mathrm{m}$ data are based on measurements, while the $<10 \mu \mathrm{m}$ data are calculated by difference.

${ }^{\mathrm{b}}$ Negative growth rate.
}

microzooplankton grazing in the $>10 \mu \mathrm{m}$ size fraction (Fig. 4b). Conversely, with the exception of the non-bloom stations, most rates of phytoplankton growth for the total and $<10 \mu \mathrm{m}$ size fractions were higher than the corresponding grazing rates. This suggests an uncoupling between grazing and growth for small cells, which, in the absence of other loss processes, will result in an accumulation of phytoplankton standing stock, particularly for the smaller size fractions.

An obvious inequality exists in the grazing rates among the different locations for the $<10 \mu \mathrm{m} \mathrm{Chl}$ 
(A)

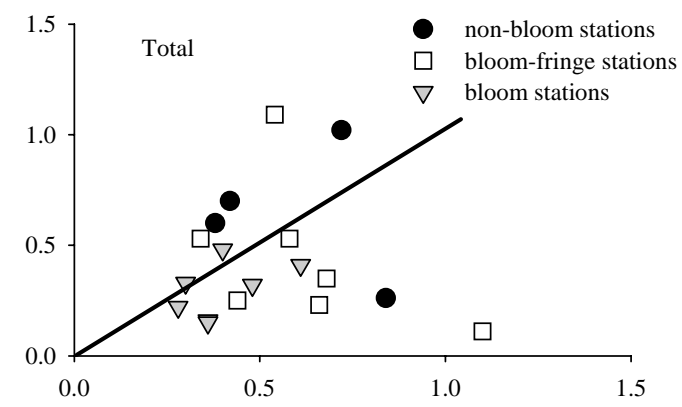

(B)
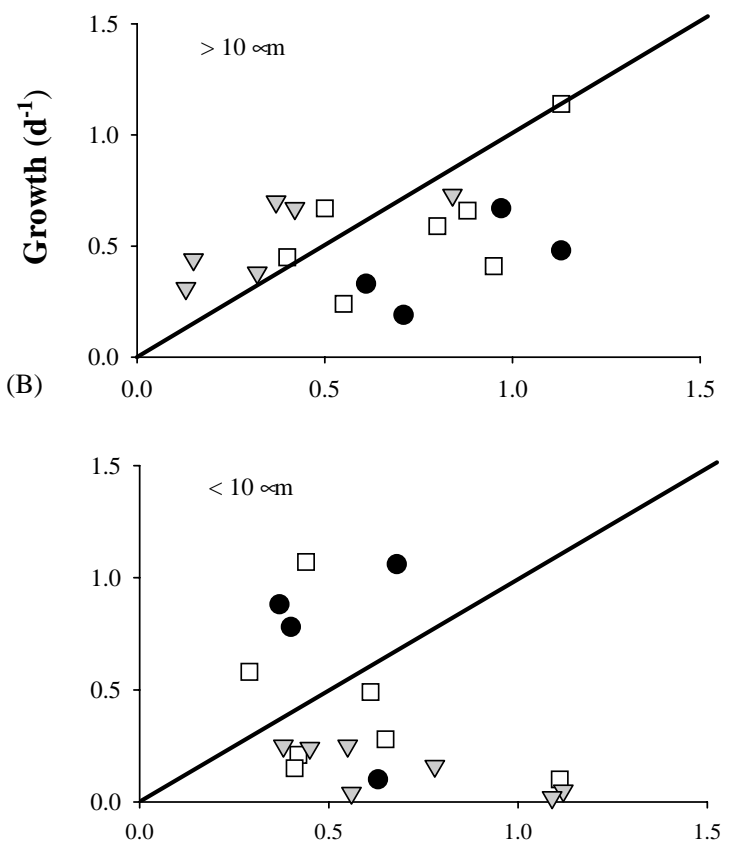

(C)

Growth $\left(\mathbf{d}^{-\mathbf{1}}\right)$

Fig. 4. Growth $\left(\mu, \mathrm{d}^{-1}\right)$ and grazing $\left(g, \mathrm{~d}^{-1}\right)$ rates for (A) total, (B) $>10 \mu \mathrm{m}$, and (C) $<10 \mu \mathrm{m} \mathrm{Chl} a$ for each biogeographical region. Line bisecting graph represents equal rates.

$a$ size fraction. It could be argued that differences in grazing rates may be a functional response to prey availability: more chlorophyll in one size fraction may lead to higher grazing pressure for cells in that size range. Can this be the reason grazing rates were higher for $>10 \mu \mathrm{m}$ Chl $a$ than for $<10 \mu \mathrm{m}$ Chl $a$ within the bloom? To explore this possibility further, $\mathrm{Chl} a$ was plotted against grazing rates for the different biogeographical regions (Fig. 5). The non-bloom and bloom-fringe stations showed high to intermediate levels of
(A)

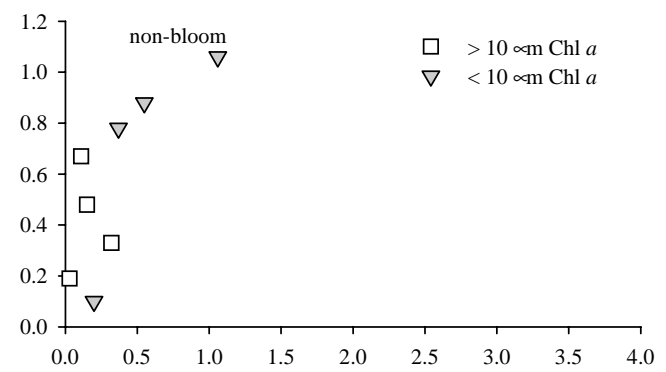

(B)
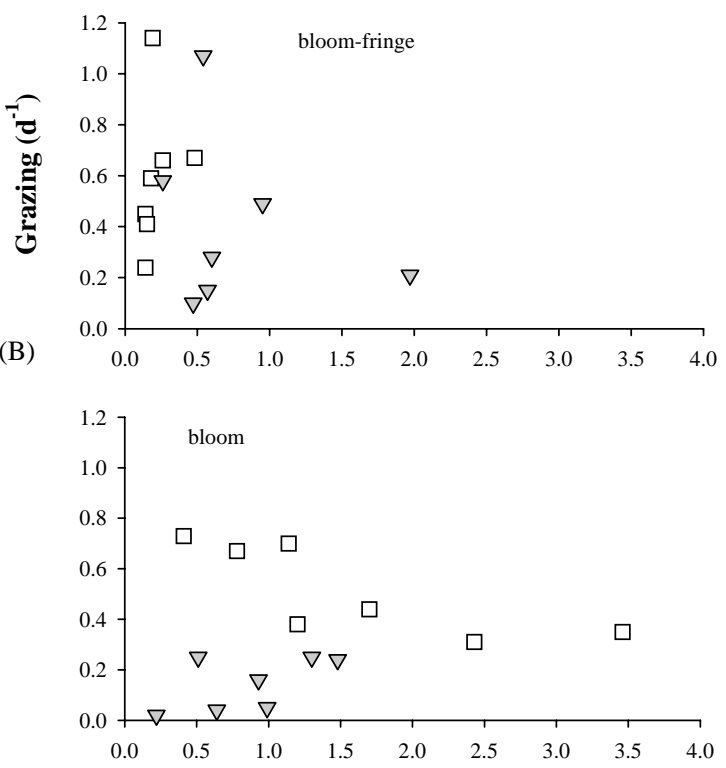

(C)

Chl $a\left(\mu \mathrm{gl}^{-1}\right)$

Fig. 5. Chl $a\left(\mu \mathrm{gl}^{-1}\right)$ and grazing $\left(g, \mathrm{~d}^{-1}\right)$ rates for $>10$ and $<10 \mu \mathrm{m}$ Chl $a$ for (A) non-bloom, (B) bloom-fringe, and (C) bloom stations.

grazing at relatively low Chl $a$ concentrations (Fig. 5a and b). At non-bloom stations, the average microzooplankton grazing/Chl $a$ ratio was 2.8 and 1.3 for $>10$ and $<10 \mu \mathrm{m}$ cells, respectively. At bloom fringe stations, the $>10 \mu \mathrm{m}$ ratio was similar to non-bloom stations (2.7), whereas the $<10 \mu \mathrm{m}$ ratio decreased to 0.5 . The bloom stations showed low levels of grazing at relatively high Chl $a$ concentrations (Fig. 5c). This phenomenon is particularly evident for the small $(<10 \mu \mathrm{m})$ phytoplankton cells, for which the microzooplankton grazing/ Chl $a$ ratio was 0.1 , compared to 0.3 for the $>10 \mu \mathrm{m}$ cells. These results, in addition to the finding that, for $<10 \mu \mathrm{m}$ 
Chl $a$, significant location-based differences existed in grazing rates but not Chl $a$ concentrations, suggests that prey size and abundance are not the only determinants of feeding rate. Given microzooplankton communities of equivalent size and composition, feeding behavior controlled by prey size and abundance would result in grazing rates proportional to Chl $a$ levels. This was not seen in this study, for no significant positive correlations existed between Chl $a$ concentrations and microzooplankton grazing rates in the $>10 \mu \mathrm{m}$ $\left(r^{2}=-0.250\right)$ or $<10 \mu \mathrm{m}\left(r^{2}=-0.075\right)$ size fractions. Instead, behaviors such as selective feeding may have been in effect.

\subsection{Microzooplankton abundance and biomass}

There were large differences among stations in microzooplankton abundance and biomass (Fig. 6). Overall, dinoflagellates and choreotrich ciliates dominated the microzooplankton community. Total microzooplankton abundance ranged from 22,000 to 227,430 cells $1^{-1}$ and total biomass from 18.4 to $164.0 \mu \mathrm{g} \mathrm{Cl}^{-1}$ (Fig. 6). Highest abundances occurred at stations 4, 14, 17 and 18 . No significant differences were seen across stations for ciliate $(F=3.33, \quad P=0.064)$ or dinoflagellate abundance $(F=1.64, P=0.230)$. Total microzooplankton $(F=2.77, P=0.095)$, and ciliate $(F=2.84, \quad P=0.090)$ biomass showed no difference among regions, whereas dinoflagellate biomass was significantly higher at bloom than at bloom-fringe stations $(F=4.63$, $P=0.027)($ Fig. 6). Highest total biomass occurred at stations 3,12, 17 and 18. Ciliate abundance $\left(r^{2}=-0.063\right)$ and biomass $\left(r^{2}=0.111\right)$ did not correlate with total $\mathrm{Chl} a$ biomass. In contrast, total microzooplankton abundance $\left(r^{2}=0.508\right)$, as well as dinoflagellate abundance $\left(r^{2}=0.610\right)$ and biomass $\left(r^{2}=0.511\right)$ significantly correlated with total phytoplankton biomass. Because a large portion of phytoplankton biomass in the bloom was associated with large diatoms, this suggests a tight coupling between microzooplankton community composition and phytoplankton size structure.

With the exception of stations 1 and 3, abundance of dinoflagellates was higher than that of ciliates (Fig. 6). Fig. 7 shows the percent contribution to total abundance of different microzooplankton taxa at each experimental station. Most stations were dominated in abundance by small round gymnodinoid and miscellaneous cylindrical and thecate dinoflagellates. Stations 10, $12,15,16$ and 18 had high abundances of Gyrodinium spp. and Protoperidinium-like dinoflagellates. These taxa are known to feed heavily, if not exclusively, on diatoms. Ciliate abundance was dominated by oligotrich ciliates between 5 and $40 \mu \mathrm{m}$ in length. Station 3 had a high abundance of tintinnid ciliates. This is not surprising, for this station is just north of the Aleutian Island archipelago, and tintinnids are primarily a coastal microzooplankton group (Beers et al., 1980; Capriulo and Carpenter, 1983; Pierce and Turner, 1993).

Fig. 7 also shows the percent contribution to total biomass by microzooplankton taxa at each experimental station. At most stations, total biomass was divided evenly between ciliates and dinoflagellates. Small gymnodinoid and miscellaneous cylindrical cells again dominated dinoflagellate biomass. Aloricate choreotrich ciliates between 20 and $40 \mu \mathrm{m}$ contributed most to ciliate biomass. Stations $8-12$ and $15-17$ saw a high biomass of ciliates $>40 \mu \mathrm{m}$. These cells were primarily the large chloroplast-retaining Laboea sp. Stations 2, 3, 8, and 15 had significant biomass contributions from the tintinnids Heliocostomella subulata, Ptychocylis spp., and Parafavella spp.

\section{Discussion}

The results of this study implicate microzooplankton as major consumers of phytoplankton production in the southeastern Bering Sea, where microzooplankton grazing rates averaged $110 \%$ (range $27-293 \%$ ) and $81 \%$ (range $2-243 \%$ ) of phytoplankton growth rates for $>10 \mu \mathrm{m}$ and $<10 \mu \mathrm{m}$ phytoplankton size fractions, respectively. These values fall within the range of grazing estimates from other coastal ecosystems (Burkill et al., 1987; Anderson et al., 1991; McManus and Ederington-Cantrell, 1992; Strom and Strom, 

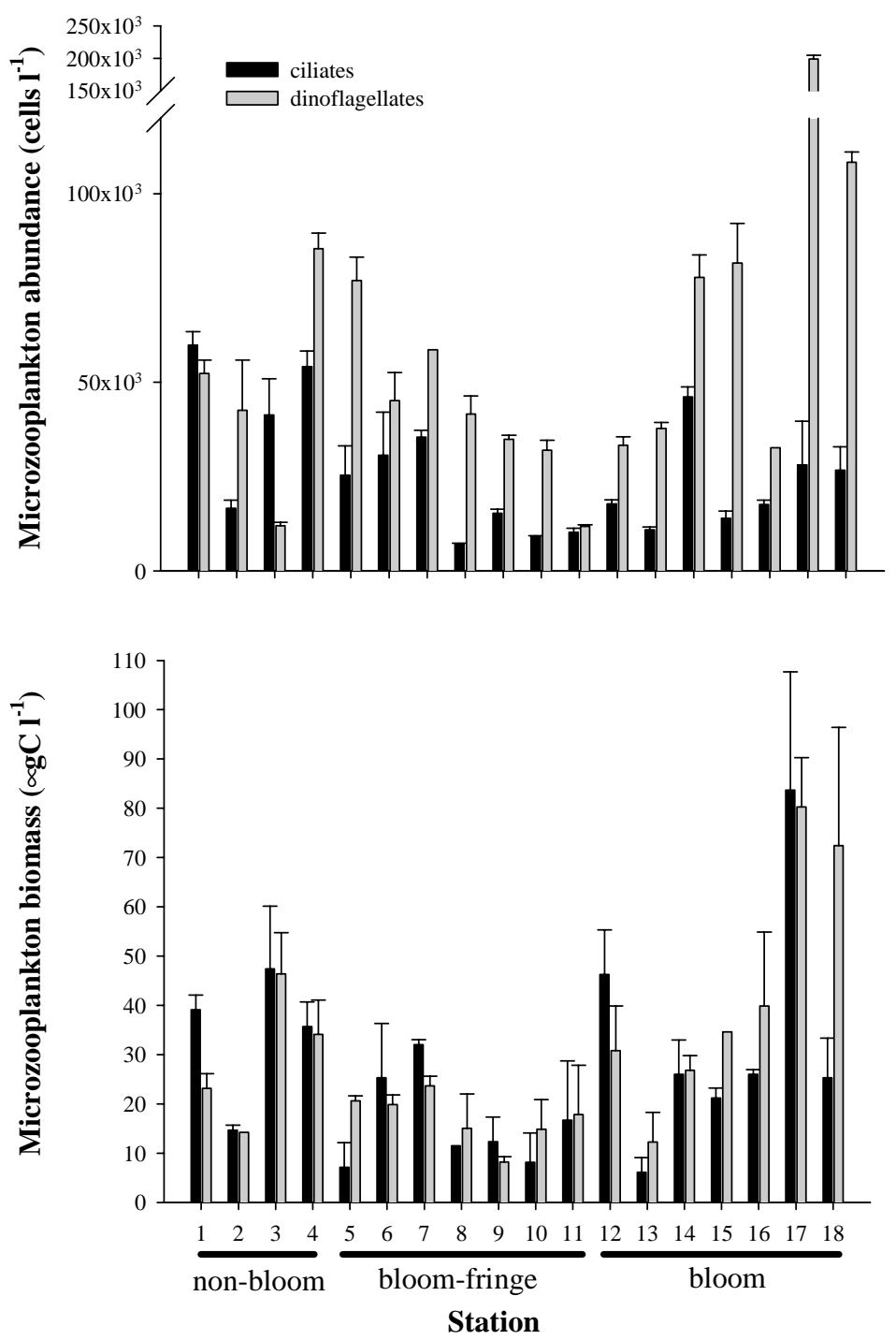

Fig. 6. Microzooplankton abundance (cells $1^{-1}$ ) and biomass $\left(\mu \mathrm{g} \mathrm{Cl}^{-1}\right)$ sampled at beginning of all dilution experiments. Values are means $(n=2)$. Error bars represent upper $95 \%$ confidence intervals.

1996; Murrell and Hollibaugh, 1998; Strom et al., 2001; Gaul and Antia, 2001). In addition, this study shows microzooplankton grazing behavior can be a structuring mechanism controlling the composition of microplankton communities. In this study, low microzooplankton grazing on cells $<10 \mu \mathrm{m}$ within the bloom contributed to the accumulation and temporal persistence of E. huxleyi.

\subsection{Methodological considerations}

Because the interpretation of our data was based on size fractionation of $\mathrm{Chl} a$, the possibility that particulates smaller than $10 \mu \mathrm{m}$, including $E$. huxleyi, were retained on the $>10 \mu \mathrm{m}$ filter must be considered. This is a recurrent problem in microbial oceanography. Our goal during this study was to select a filter type and filtering 

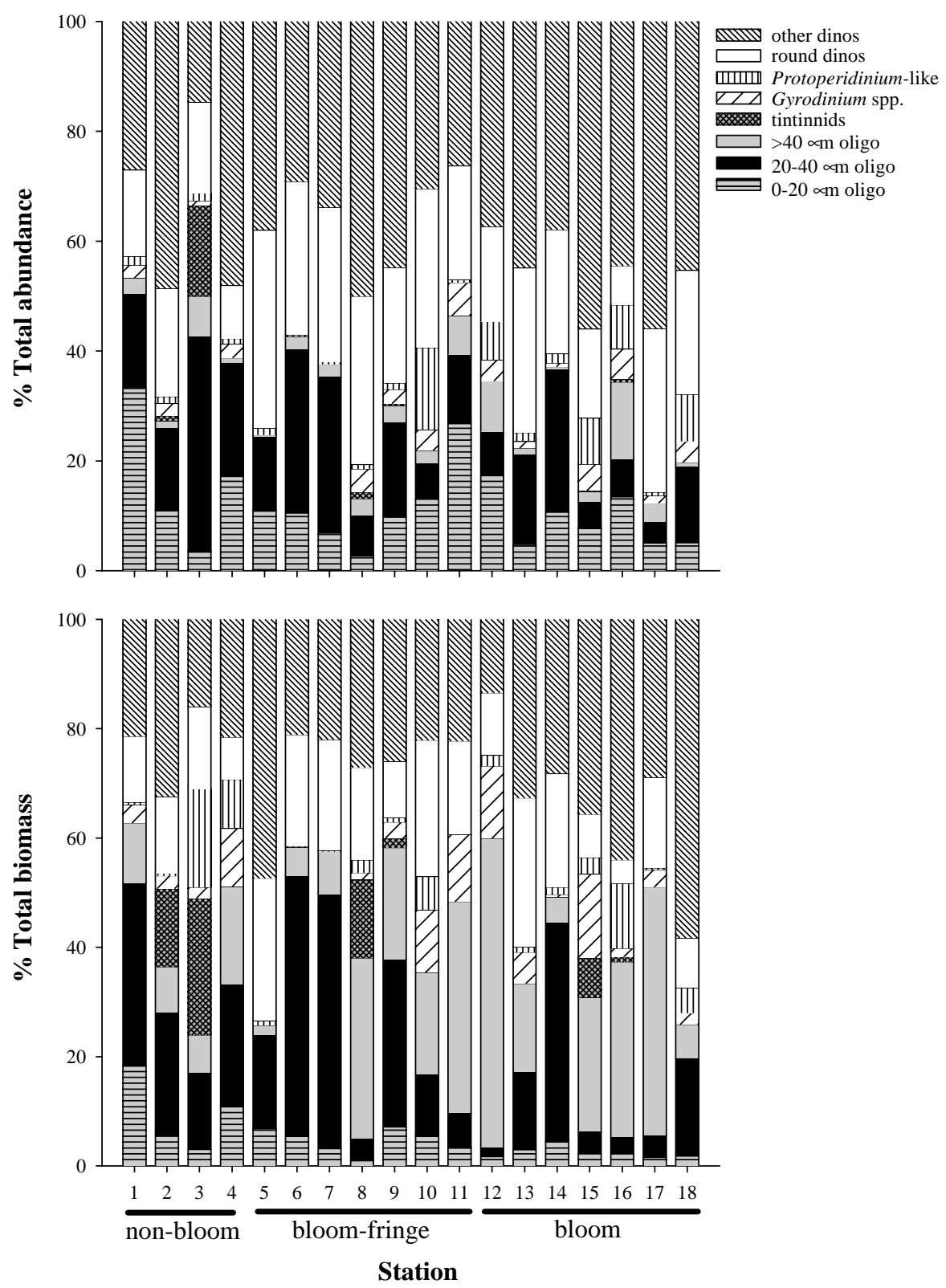

Fig. 7. Percent contribution of individual taxa to microzooplankton abundance and biomass taken at beginning of all dilution experiments. Darker shading shows contribution from ciliates, while lighter shading shows contribution from dinoflagellates. Values are means $(n=2)$. dino: dinoflagellates; oligo: oligotrichs (aloricate choreotrich ciliates); Gymno: Gymnodinium.

methodology that minimized this potential error. Due to time factors involved with preparing Nitex mesh filters, as well as the potential of Nitex mesh to stretch, we used $10 \mu \mathrm{m}$ polycarbonate filters to size-fractionate Chl $a$. A criticism of polycarbo- nate filters is that they clog readily. To minimize the potential for clogging, filtrate volumes in this study were adjusted according to ambient microbial biomass. However, because we do not have data showing the effectiveness of this strategy, the 
potential for capture of small cells on polycarbonate filters must be kept in mind when interpreting our data.

A recent criticism of the dilution method is that differential numerical growth responses of grazers occur throughout the incubation, although grazer growth rates as a function of dilution are not routinely measured (Dolan et al., 2000). Higher growth rates of microzooplankton in the lessdilute treatments result in higher grazing rates on the phytoplankton compared to highly dilute treatments. This would increase the slope of the dilution regression, resulting in artificially elevated phytoplankton growth and microzooplankton grazing estimates. Dolan et al. (2000) showed apparent growth rates of tintinnids and oligotrich ciliates decreased with increasing fraction of PFW at temperatures ranging from $16.1^{\circ} \mathrm{C}$ to $18.6^{\circ} \mathrm{C}$. Unfortunately, the potential for microzooplankton growth to vary as a function of dilution was not accounted for in this study, where temperatures ranged from $5^{\circ} \mathrm{C}$ to $10^{\circ} \mathrm{C}$. In this study, we found numerical dominance by heterotrophic dinoflagellates, and equal contributions to biomass from both groups. As demonstrated by Strom and Morello (1998), heterotrophic dinoflagellates show lower growth rates (range $0.41-0.48 \mathrm{~d}^{-1}$ ) than ciliate growth rates (range $0.77-1.01 \mathrm{~d}^{-1}$ ) when fed identical diets at a low, constant temperature of $13^{\circ} \mathrm{C}$. In an experiment by Nejstgaard et al. (1997), microzooplankton biomass in the undiluted bottles did not change throughout the course of dilution experiments, leading the authors to suggest that microzooplankton net growth rate during incubations was zero. Consequently, the effects of variable grazer response to dilution in our experiments can only be hypothesized until published data shows that growth rates of high latitude microzooplankton communities (i.e. significant contribution by heterotrophic dinoflagellates) are affected by resource gradients on 24-h time scales.

\subsection{Phytoplankton growth estimates}

Despite low ambient $\mathrm{NO}_{3}^{-}$and $\mathrm{PO}_{4}^{3-}$ concentrations, phytoplankton growth rates were surprisingly high. Total phytoplankton growth rates averaged $0.60,0.62$, and $0.40 \mathrm{~d}^{-1}$ for non-bloom, bloom-fringe, and bloom stations, respectively. These values correspond to $0.87,0.90$, and $0.58 \mathrm{~d}^{-1}$. Phytoplankton growth was not nutrient limited throughout our study for $<10 \mu \mathrm{m} \mathrm{Chl} a$, suggesting the phytoplankton community constituting this size fraction was adapted to, and perhaps in part structured by, low ambient nutrient concentrations. Cells $>10 \mu \mathrm{m}$ showed nutrient limitation throughout this study. However, biomass in this size fraction was quite high at the bloom stations, and can be attributed to the high abundance of large Nitzschia spp. These diatoms have a high surface-volume ratio resulting from their needle-like morphology. This morphology apparently allows them to flourish in $\mathrm{NO}_{3}^{-}$depleted regions. The occurrence of Nitzschia sp. also was observed in a western English Channel E. huxleyi bloom (Garcia-Soto et al., 1995). Surprisingly, we found that phytoplankton growth was occasionally adversely affected by nutrient addition, especially in the $<10 \mu \mathrm{m}$ size fraction. The target levels of $2 \mu \mathrm{M} \mathrm{PO}_{4}^{3-}$ and $20 \mu \mathrm{M} \mathrm{NO}_{3}^{-}$ added to our dilution series are not above levels frequently encountered in the summer Bering Sea (Shiomoto, 1999). However, because this study occurred during a period of low ambient $\mathrm{NO}_{3}^{-}$and $\mathrm{PO}_{4}^{3-}$ concentrations, it is possible that the small phytoplankton were conditioned to these low nutrient levels. The sudden increase in nutrients from our additions may have had sub-lethal negative effects on the phytoplankton growth. However, this explanation is only hypothetical. To our knowledge, no published data suggest this mechanism; consequently, a definitive explanation for our finding is lacking.

Interestingly, we encountered high concentrations of $\mathrm{NH}_{4}^{+}$during this study. Average $\mathrm{NH}_{4}^{+}$ concentration across all stations during this study was $3.15 \mu \mathrm{M}$ (range $0.13-6.39 \mu \mathrm{M}$ ). In a laboratory experiment with isolated E. huxleyi from Ocean Station Papa in the subarctic northeast Pacific, Varela and Harrison (1999) showed that uptake rates of $\mathrm{NO}_{3}^{-}$were reduced to half their maximum values at $0.24 \mu \mathrm{M} \mathrm{NH}_{4}^{+}$. Contrary to these results, Dortch et al. (1991) showed that $\mathrm{NH}_{4}^{+}$enhanced $\mathrm{NO}_{3}^{-}$uptake rates, whereas Kristiansen and Lund (1989) showed $\mathrm{NH}_{4}^{+}$had no effect on $\mathrm{NO}_{3}^{-}$uptake 
rates. It seems an interaction may exist between $\mathrm{NH}_{4}^{+}$and $\mathrm{NO}_{3}^{-}$uptake, but the nature of the interaction appears to depend upon many factors, including environmental conditions, the species under study and its physiological state (Dortch, 1990). Because this was not a target of our study, it remains unknown whether the high $\mathrm{NH}_{4}^{+}$concentrations encountered in the Bering Sea affected $\mathrm{NO}_{3}^{-}$uptake, especially with reference to our nutrient additions.

\subsection{Microzooplankton grazing, biomass, and abundance}

Dilution experiments performed by Levasseur et al. (1996) during a bloom of E. huxleyi in the Raunefjorden fjord in Norway showed intrinsic growth rates of $E$. huxleyi $\left(1.08-1.23 \mathrm{~d}^{-1}\right)$ were approximately matched by microzooplankton grazing $\left(1.02-1.32 \mathrm{~d}^{-1}\right)$. Those results are in contrast to those reported from an experiment by Nejstgaard et al. (1997). They found E. huxleyi specific growth rates exceeded microzooplankton grazing rates in all experiments. Our data from the Bering Sea are in accord with Nejstgaard et al. (1997). In bloom waters, microzooplankton grazing rates were only $28 \%$ of phytoplankton growth rates for $<10 \mu \mathrm{m} \mathrm{Chl} a$, and grazing rates were significantly lower than at non-bloom stations. Also apparent was a shift in grazing pressure within the bloom from small to large phytoplankton. It could be argued that the shift in grazing pressure within the bloom to cells $>10 \mu \mathrm{m}$ results from the substantial increase in biomass in that size fraction. Chl $a$ associated with cells $>10 \mu \mathrm{m}$ increased on average from 0.15 to $1.58 \mu \mathrm{gl}^{-1}$ from non-bloom to bloom stations, respectively. However, this explanation is unlikely: paralleling the increase in large phytoplankton was the increase in biomass of Gyrodinium spp. and Protoperidiniumlike dinoflagellates. These microzooplankton feed heavily on diatoms. E. huxleyi, which is approximately $5-8 \mu \mathrm{m}$, is most likely too small to be grazed efficiently by these large diatom-consuming microzooplankton. Phytoplankton $<10 \mu \mathrm{m}$ are primarily grazed by protists $\leqslant 20 \mu \mathrm{m}$ (Sherr and Sherr, 1994), which, with a few exceptions, are too small to graze on large diatoms. Surprisingly, despite a significant reduction in grazing rates from non-bloom to bloom stations, small microzooplankton $(10-20 \mu \mathrm{m})$ capable of grazing $E$. huxleyi and other small phytoplankton increased slightly in abundance $\left(51,631-61,825\right.$ cells $\left.^{-1}\right)$ and biomass $\left(10.56-12.87 \mu \mathrm{g} \mathrm{Cl}^{-1}\right)$ from non-bloom to bloom stations.

In light of the low grazing rates on phytoplankton $<10 \mu \mathrm{m}$, what then supports the high abundance and biomass of small microzooplankton? Although not numerically abundant within the bloom, nanophytoplankton other than E. huxleyi could have contributed to the diets of small microzooplankton. In addition, although we did not measure heterotrophic bacterial biomass, it is possible bacterial biomass was high enough to support the nutritional demands of small microzooplankton. Without an understanding of species-specific grazing relationships, an unequivocal explanation as to what supports high microzooplankton biomass in the small size fractions within the bloom is lacking. A definitive answer would help explain why E. huxleyi can accumulate to bloom proportions, and may give mechanistic information as to why grazing pressure was low on the E. huxleyi bloom.

One possibility that may account for low grazing rates on the E. huxleyi bloom would be top-down control on microzooplankton. Perhaps grazing on small microzooplankton by large microzooplankton and metazoans are reducing grazing pressure on small algae by limiting small microzooplankton biomass? These trophic cascades have been described in oceanic ecosystems (Shiomoto et al., 1997; Calbet et al., 2001). If top down control on microzooplankton were in effect, low abundance and biomass of microzooplankton in the bloom would be expected. That was not seen in this study; rather, our estimates of microzooplankton abundance and biomass are higher than previously reported for this region. In a study to determine whether protozoan biomass was sufficient to meet daily carbon requirements for firstfeeding larval pollock, Howell-Kübler et al. (1996) measured abundance (300-6,233 cells $\left.1^{-1}\right)$ and biomass $\left(0.60-10.2 \mu \mathrm{g} \mathrm{Cl}^{-1}\right)$ for microzooplankton $>20 \mu \mathrm{m}$ in the southeastern Bering Sea in April of 1992. Because our measurements of biomass 
and abundance included all microzooplankton $>10 \mu \mathrm{m}$, we subsequently estimated abundance and biomass of microzooplankton $>20 \mu \mathrm{m}$ only for comparison with their findings. These corrected abundance values range from 9,112 to 70,834 cells $^{-1}$ and biomass values from 9.5 to $132.5 \mu \mathrm{g} \mathrm{Cl}^{-1}$. These are still higher than those reported for the Bering Sea in April 1992 by Howell-Kübler et al. (1996), but more closely resemble their estimates from Shelikof Strait in May 1990, where abundance and biomass during the onset of a diatom bloom ranged from 850 to 14,960 cells $^{-1}$ and 1.3 to $70.7 \mu \mathrm{g} \mathrm{Cl}^{-1}$, respectively. Because measurements of microzooplankton abundance and biomass are higher than previously reported for this region, especially in the bloom, it seems unlikely that top-down control is suppressing microzooplankton grazing on E. huxleyi.

In general, ciliate abundance and biomass showed little variation among stations. Conversely, heterotrophic dinoflagellate abundance and biomass significantly correlated with phytoplankton biomass. Because most of the biomass increase was from large phytoplankton, specifically diatoms, this suggests a tight coupling between dinoflagellates and diatoms. Levinsen et al. (2000) witnessed a similar increase of large microzooplankton in response to a coastal western Greenland diatom bloom, and suggested this coupling was also a result of top-down regulation: i.e. the high biomass of large microzooplankton within a diatom bloom might have resulted indirectly from increased abundance of diatoms, an alternate food source for macrozooplankton. The data presented here, however, suggest bottomup control may be equally important. At stations $12,14,16,17$, and 18, where large phytoplankton contributed $>50 \%$ of total Chl $a$, microzooplankton grazed over $100 \%$ of the large phytoplankton growth. By averaging the $\mathrm{Chl} a$ and grazing rates over these 5 stations, and assuming a carbon: Chl $a$ ratio of 50 (Booth et al., 1993), microzooplankton were consuming $42 \mu \mathrm{g} \mathrm{Cl}^{-1} \mathrm{~d}^{-1}$. Assuming a microzooplankton gross growth efficiency of $\sim 30 \%$ (Straile, 1997), microzooplankton production was potentially quite high at $13 \mu \mathrm{g} \mathrm{Cl}^{-1} \mathrm{~d}^{-1}$. If diatoms are sub-optimal diets for crustacean zooplankton as the literature suggests, microzooplankton production through direct consumption of diatoms may provide the necessary carbon for metazoan and larval fish predators, thus holding the diatom-copepod-fish food chain together.

Another mechanism that may account for low grazing on small cells within the bloom is selective grazing on prey other than E. huxleyi. Coccoliths surrounding E. huxleyi may act as a morphological or chemical signal, indicating E. huxleyi as an unpalatable or indigestible prey. Signaling is defined as the transfer of information between two organisms by a biogenic stimulus that can be perceived by a sensory system and evoke an adaptive response (Dusenbery, 1992). If a micrograzer receives negative signals from contact with inorganic coccoliths, reduced grazing pressure on E. huxleyi could result, thus leading to the possibility of bloom formation, as has been witnessed in the southeastern Bering Sea since 1997. This may be especially problematic if detached coccoliths accumulate in the water column once shed from a healthy cell. Detached coccoliths can substantially outnumber healthy cells. In a western English Channel E. huxleyi bloom, cells and detached coccoliths presented densities of $>2,000$ cells ml $^{-1}$ and 350,000 coccoliths $\mathrm{ml}^{-1}$ (Garcia-Soto et al., 1995). High densities of detached coccoliths may represent senescent stages of a bloom, thus signaling that the prey are physiologically and nutritionally inferior to alternate prey; such signaling could contribute to bloom persistence.

A second possible signaling mechanism and alternative explanation for low grazing in the bloom would be the ability of E. huxleyi to chemically defend itself. E. huxleyi, like many taxa from the Haptophyceae and Dinophyceae, is a notorious bloom-forming species that produces concentrated intracellular DMSP (Wolfe, 2000). DMSP is considered to be nontoxic and serves as an excellent compatible osmolyte (Dickson and Kirst, 1987) and may additionally act as a cryoprotectant (Karsten et al., 1996). The mechanism for chemical feeding deterrence by DMSP or its cleavage products is still poorly understood. However, Wolfe and Strom (unpubl. data) showed the dinoflagellates Amphidinium longum and 
Gymnodinium sp. readily ingest $E$. huxleyi with low DMSP lyase activity (Wolfe, 2000), but avoid grazing on high-lyase E. huxleyi. These prey strains were morphologically identical, with only slight variations in chemical composition (total C, $\mathrm{N}$, protein, lipid, carbohydrate, mineral, and dry weight). Although other unknown mechanisms may contribute to feeding selectivity, Wolfe (2000) states the only clear polymorphism that covaries with feeding selectivity is DMSP lyase activity, which most likely results in feeding deterrence by microzooplankton.

\section{Conclusions}

It is clear from our data that microzooplankton are significant, if not the primary, grazers of phytoplankton production in the Bering Sea during summer. This finding is consistent with a growing body of observations from both oceanic and coastal ecosystems. Because algal blooms are seasonally predictable in shelf environments and provide satiating levels of biomass on short time scales, they are often associated with high biomass of organisms from higher trophic levels. This is especially true in the southeastern Bering Sea, where primary production indirectly supports one of the world's largest fisheries, as well as sustaining large populations of migratory birds and marine mammals. Because of the ecological importance of this primary production, it is necessary to allocate the grazed production into the appropriate consumer category if we are to make predictions as to how this and other large ecosystems will adapt to climate variability.

Despite low ambient $\mathrm{NO}_{3}^{-}$and $\mathrm{PO}_{4}^{3-}$ levels and water temperatures, phytoplankton growth rates for $>10$ and $<10 \mu \mathrm{m} \mathrm{Chl} a$ size fractions were high across all biogeographic regions. Microzooplankton community grazing varied among locations, but in general seemed to shift from selective grazing on small phytoplankton cells outside the bloom to selective grazing on large cells within the bloom. The data presented here implicate reduced microzooplankton grazing as contributing to the formation and temporal persistence of the $E$. huxleyi bloom. Unfortunately, the ultimate fate of the coccolithophore bloom remains unknown. Because microzooplankton grazing does not appear to be a major loss process for E. huxleyi, alternative explanations for its fate may include horizontal or vertical advection, viral lysis, or decreased production as ambient PAR decreases with progression of winter months.

\section{Acknowledgements}

We acknowledge the captain and crew of the RV Alpha Helix and George L. Hunt Jr. for cruise leadership. We wish to thank Heloise Chenelot for conducting nutrient analysis at sea, and Dr. Terry Whitledge for sharing nutrient data and advice in its interpretation. Dr. Gordon Wolfe provided invaluable comments during the preparation of this manuscript. We would also like to thank Dr. Stephen Sulkin for use of facilities at Shannon Point Marine Center. This research was grant supported by NSF OPP-9617287 and OPP9819251, Sigma Xi Grant-in-Aid of Research, and Graduate Research Funds through Western Washington University and its Huxley College.

\section{References}

Admiraal, W., Venekamp, L.A.H., 1986. Significance of tintinnid grazing during blooms of Phaeocystis pouchetti (Haptophyceae) in Dutch coastal waters. Netherlands Journal of Sea Research 20, 61-66.

Alexander, V., Niebauer, H.J., 1981. Oceanography of the eastern Bering Sea ice-edge zone in spring. Limnology and Oceanography 26 (6), 1111-1125.

Anderson, T., Schartau, A.K.L., Paasche, E., 1991. Quantifying external and internal nitrogen and phosphorous pools, as well as nitrogen and phosphorous supplied through remineralization, in coastal marine plankton by means of a dilution technique. Marine Ecological Progress Series 69, $67-80$.

Ban, S., Burns, C., Castel, J., Chaudron, Y., Christou, E., Escribano, R., Umani, S.F., Gasparini, S., Ruiz, F.G., Hoffmeyer, M., Ianora, A., Kang, H., Laabir, M., Lacoste, A., Miralto, A., Ning, X., Poulet, S., Rodriguez, V., Runge, J., Shi, J., Starr, M., Uye, S., Wang, Y., 1997. The paradox of diatom-copepod interactions. Marine Ecological Progress Series 157, 287-293. 
Beers, J.R., Reid, F.M.H., Stewart, G.L., 1980. Microplankton population structure in southern California nearshore waters in late spring. Marine Biology 60, 209-226.

Booth, B.C., Lewin, J., Postel, J.R., 1993. Temporal variation in the structure of autotrophic and heterotrophic communities in the subarctic Pacific. Progress in Oceanography 32 (1-4), 57-100.

Burkill, P.H., Mantoura, R.F.C., Llewellyn, C.A., Owens, N.J.P., 1987. Microzooplankton grazing and selectivity of phytoplankton in coastal waters. Marine Biology 93, 581-590.

Burkill, P.H., Edwards, E.S., John, A.W.G., Sleigh, M.A., 1993. Microzooplankton and their herbivorous activity in the northeastern Atlantic Ocean. Deep-Sea Research II 40 (1/2), 479-493.

Buskey, E.J., 1997. Behavioral components of feeding selectivity of the heterotrophic dinoflagellate Protoperidinium pellucidium. Marine Ecological Progress Series 153, 77-89.

Calbet, A., Landry, M.R., Nunnery, S., 2001. Bacteriaflagellate interactions in the microbial food web of the oligotrophic subtropical North Pacific. Aquatic Microbial Ecology 23, 283-292.

Capriulo, G.M., Carpenter, E.J., 1983. Abundance, species composition and feeding impact of tintinnid micro-zooplankton in central Long Island Sound. Marine Ecological Progress Series 10, 277-288.

Capriulo, G.M., Sherr, E.B., Sherr, B.F., 1991. Trophic behavior and related community feeding activities of heterotrophic marine protists. In: Reid, P.C., Turley, C.M., Burkill, P.H. (Eds.), Protozoa and their role in marine processes. Springer, Berlin, pp. 219-265.

Chew, V., 1976. Comparing treatment means: a compendium. Hortscience 11 (4), 348-357.

Dickson, D.M.J., Kirst, G.O., 1987. Osmotic adjustment in marine eukaryotic algae: the role of inorganic ions, quaternary ammonium, tertiary sulfonium and carbohydrate solutes. New Phytologist 106, 645-655.

Dolan, J.R., Gallegos, C.L., Moigis, A., 2000. Dilution effects on microzooplankton in dilution grazing experiments. Marine Ecological Progress Series 200, 127-139.

Dortch, Q., 1990. The interaction between ammonium and nitrate uptake in phytoplankton. Marine Ecology Progress Series 61, 183-201.

Dortch, Q., Thompson, P.A., Harrison, P.J., 1991. Short-term interaction between nitrate and ammonium uptake in Thalassiosira pseudonana: effect of preconditioning nitrogen source and growth rate. Marine Biology 110, 183-193.

Dusenbery, D.B., 1992. Sensory Ecology. W.H. Freeman, New York.

Dussart, B.M., 1965. Les différentes catégories de plancton. Hydrobiologia 26, 72-74.

Gallegos, C.L., 1989. Microzooplankton grazing on phytoplankton in the Rhode River, Maryland: nonlinear feeding kinetics. Marine Ecological Progress Series 57, 23-33.

Garcia-Soto, C., Fernández, E., Pingree, R.D., Harbour, D.S., 1995. Evolution and structure of a shelf coccolithophore bloom in the Western English Channel. Journal of Plankton Research 17 (11), 2011-2036.

Gaul, W., Antia, A.N., 2001. Taxon-specific growth and selective microzooplankton grazing of phytoplankton in the Northeast Atlantic. Journal of Marine Systems 30, 241-261.

Gifford, D.J., 1988. Impact of grazing by microzooplankton in the Northwest Arm of Halifax Harbour, Nova Scotia. Marine Ecological Progress Series 47, 249-258.

Gifford, D.J., 1991. The protozoa-metazoan trophic link in pelagic ecosystems. Journal of Protozoology 38, 81-86.

Hansen, P.J., 1989. The red tide dinoflagellate Alexandrium tamarense: effects on behaviour and growth of a tintinnid ciliate. Marine Ecological Progress Series 53, 105-116.

Hansen, P.J., Calado, A.J., 1999. Phagotrophic mechanisms and prey selection in free-living dinoflagellates. Journal of Eukaryotic Microbiology 46 (4), 382-389.

Holligan, P.J., Groom, S.B., Harbour, D.S., 1993. What controls the distribution of the coccolithophore, Emiliania huxleyi, in the North Sea? Fisheries Oceanography 2 (3/4), 175-183.

Hood, D.W., 1999. PROBES: Processes and resources of the eastern Bering Sea shelf. In: Loughlin, T.R., Ohtani, K. (Eds.), Dynamics of the Bering Sea. University of Alaska Sea Grant, AK-SG-99-03, Fairbanks, pp. 387-407.

Howell-Kübler, A.N., Lessard, E.J., Napp, J.M., 1996. Springtime microprotozoan abundance and biomass in the southeastern Bering Sea and Shelikof Strait, Alaska. Journal of Plankton Research 18 (5), 731-745.

Hunt, G.L., Baduini, C.L., Brodeur, R.D., Coyle, K.O., Kachel, N.B., Napp, J.M., Salo, S.A., Schumacher, J.D., Stockwell, D.A., Whitledge, T.E., Zeeman, S.I., 1999. The Bering Sea in 1998: the second consecutive year of extreme weather-forced anomalies. EOS, Transactions, American Geophysical Union 80 (47), 564-566.

Jacobson, D.M., Anderson, D.M., 1986. Thecate heterotrophic dinoflagellates: feeding behavior and mechanisms. Journal of Phycology 22, 249-258.

Karsten, U., Kück, K., Vogt, C., Kirst, G.O., 1996. Dimethylsulfoniopropionate production in phototrophic organisms and its physiological function as a cryoprotectant. In: Kiene, R.P., Visscher, P., Kirst, G., Keller, M. (Eds.), Biological and Environmental Chemistry of DMSP and Related Sulfonium Compounds. Plenum Press, New York, pp. 143-153.

Kleppel, G.S., Holliday, D.V., Pieper, R.E., 1991. Trophic interactions between copepods and microplankton: a question about the role of diatoms. Limnology and Oceanography 36 (1), 172-178.

Kristiansen, S., Lund, B.A., 1989. Nitrogen cycling in the Barents Sea-I. Uptake of nitrogen in the water column. Deep-Sea Research 36, 255-268.

Landry, M.R., 1993. Estimating rates of growth and grazing mortality of phytoplankton by the dilution method. In: Kemp, P.F., Sherr, B.F., Sherr, E.B., Cole, J.J. (Eds.), Handbook of Methods in Aquatic Microbial Ecology. Lewis Publishers, Boca Raton, FL, pp. 715-722. 
Landry, M.R., Hassett, R.P., 1982. Estimating the grazing impact of marine microzooplankton. Marine Biology 67, 283-288.

Lessard, E.J., 1991. The trophic role of heterotrophic dinoflagellates in diverse marine environments. Marine Microbial Food Webs 5, 49-58.

Lessard, E.J., Murrell, M.C., 1998. Microzooplankton herbivory and phytoplankton growth in the northwestern Sargasso Sea. Aquatic Microbial Ecology 16, 173-188.

Levasseur, M., Michaud, S., Egge, J., Cantin, G., Nejstgaard, J.C., Sanders, R., Fernandez, E., Solberg, P.T., Heimdal, B., Gosselin, M., 1996. Production of DMSP and DMS during a mesocosm study of an Emiliania huxleyi bloom: influence of bacteria and Calanus finmarchicus grazing. Marine Biology 126, 609-618.

Levinsen, H., Turner, J.T., Nielsen, T.G., Hansen, B.W., 2000. On the trophic coupling between protists and copepods in arctic marine ecosystems. Marine Ecology Progress Series 204, 65-77.

Loughlin, T.R., Sukhanova, I.N., Sinclair, E.H., Ferrero, R.C., 1999. Summary of biology and ecosystem dynamics in the Bering Sea. In: Loughlin, T.R., Ohtani, K. (Eds.), Dynamics of the Bering Sea. University of Alaska Sea Grant, AK-SG99-03, Fairbanks, pp. 387-407.

Lorenzen, C.J., 1966. A method for the continuous measurement of in vivo chlorophyll concentration. Deep-Sea Research 13, 223-227.

McManus, G.B., Ederington-Cantrell, M.C., 1992. Phytoplankton pigments and growth rates, and microzooplankton grazing in a large temperate estuary. Marine Ecological Progress Series 87, 77-85.

Miralto, A., Barone, G., Romano, G., Poulet, S.A., Ianora, A., Russo, G.L., Buttino, I., Mazzarella, G., Laabir, M., Cabrini, M., Giacobbe, M.G., 1999. The insidious effect of diatoms on copepod reproduction. Nature 402, 173-176.

Murrell, M.C., Hollibaugh, J.T., 1998. Microzooplankton grazing in the northern San Francisco bay measured by the dilution method. Aquatic Microbial Ecology 15, 53-63.

Nejstgaard, J.C., Gismervik, I., Solberg, P.T., 1997. Feeding and reproduction by Calanus finmarchicus, and microzooplankton grazing during mesocosm blooms of diatoms and the coccolithophore Emiliania huxleyi. Marine Ecology Progress Series 147, 197-217.

Neuer, S., Cowles, T.J., 1994. Protist herbivory in the Oregon upwelling system. Marine Ecology Progress Series 113, 147-162.

Parsons, T.R., Maita, Y., Lalli, C.M., 1984. A Manual of Chemical and Biological Methods for Seawater Analysis. Pergamon Press, New York, pp. 107-110.

Pierce, R.W., Turner, J.T., 1993. Global biogeography of marine tintinnids. Marine Ecological Progress Series 94, $11-26$.

Putt, M., Stoecker, D.K., 1989. An experimentally determined carbon: volume ratio for marine 'oligotrichous' ciliates from estuarine and coastal waters. Limnology and Oceanography $34,1097-1103$.
Rivkin, R.B., Putland, J.N., Anderson, M.R., Deibel, D., 1999. Microzooplankton bacterivory and herbivory in the NE subarctic Pacific. Deep Sea Research II 46 (1999), 2579-2618.

Roff, J.C., Hopcroft, R.R., 1986. High precision microcomputer based measuring system for ecological research. Canadian Journal of Fisheries and Aquatic Science 43, 2044-2048.

Sherr, E.B., Sherr, B.F., 1988. Role of microbes in pelagic food webs: a revised concept. Limnology and Oceanography 33 (5), 1225-1227.

Sherr, E.B., Sherr, B.F., 1992. Trophic roles of pelagic protists: phagotrophic flagellates as herbivores. Arch Hydrobiol Beih Ergebn Limnol 37, 165-172.

Sherr, E.B, Sherr, B.F., 1994. Bacterivory and herbivory: key roles of phagotrophic protists in pelagic food webs. Microbial Ecology 28, 223-235.

Shiomoto, A., 1999. Effect of Nutrients on Phytoplankton Size in the Bering Sea Basin. In: Loughlin, T.R., Ohtani, K. (Eds.), Dynamics of the Bering Sea. University of Alaska Sea Grant, AK-SG-99-03, Fairbanks, pp. 193-215.

Shiomoto, A., Tadokoro, K., Nagasawa, K., Ishida, Y., 1997. Trophic relations in the subarctic North Pacific ecosystem: possible feeding effect from pink salmon. Marine Ecological Progress Series 150, 75-85.

Springer, A.M., McRoy, C.P., Flint, M.V., 1996. The Bering Sea Green Belt: shelf-edge processes and ecosystem production. Fisheries Oceanography 5 (3/4), 205-223.

Steidinger, K.A., Tangen, K., 1996. Dinoflagellates. In: Tomas, C.R. (Ed.), Identifying Marine Diatoms and Dinoflagellates. Academic Press, San Diego, pp. 387-570.

Stoecker, D.K., 1999. Mixotrophy among dinoflagellates. Journal of Eukaryotic Microbiology 46, 397-401.

Stoecker, D.K., Capuzzo, J.M., 1990. Predation on protozoa: its importance to zooplankton. Journal of Plankton Research 12 (5), 891-908.

Stoecker, D.K., Gifford, D.J., Putt, M., 1995. Preservation of marine planktonic ciliates: losses and cell shrinkage during fixation. Marine Ecological Progress Series 110, 293-299.

Straile, D., 1997. Gross growth efficiencies of protozoan and metazoan zooplankton and their dependence on food concentration, predator-prey weight ratio, and taxonomic group. Limnology and Oceanography 42 (6), 1375-1385.

Strom, S.L., Morello, T.A., 1998. Comparative growth rates and yields of ciliates and heterotrophic dinoflagellates. Journal of Plankton Research 20 (3), 571-584.

Strom, S.L., Strom, M.W., 1996. Microplankton growth, grazing, and community structure in the northern Gulf of Mexico. Marine Ecological Progress Series 130, 229-240.

Strom, S.L., Brainard, M.A., Holmes, J.L., Olson, M.B., 2001. Phytoplankton blooms are strongly impacted by microzooplankton grazing in coastal North Pacific waters. Marine Biology 138, 355-368.

Sukhanova, I.N., Semina, H.J., Venttsel, M.V., 1999. Spatial Distribution and Temporal Variability of Phytoplankton in the Bering Sea. In: Loughlin, T.R., Ohtani, K. (Eds.), 
Dynamics of the Bering Sea. University of Alaska Sea Grant, AK-SG-99-03, Fairbanks, pp. 193-215.

Teegarden, G.J., Cembella, A.D., 1996. Grazing of toxic dinoflagellates, Alexandrium spp., by adult copepods of coastal Maine: implications for the fate of paralytic shellfish toxins in marine food webs. Journal of Experimental Marine Biology and Ecology 196, 145-176.

Turner, J.T., Tester, P.A., 1997. Toxic marine phytoplankton, zooplankton grazers, and pelagic food webs. Limnology and Oceanography 42, 1203-1214.

Vance, T.C., Schumacher, J.D., Stabeno, P.J., Baier, C.T., Wyllie-Echeverria, T., Tynan, C.T., Brodeur, R.D., Napp, J.M., Coyle, K.O., Decker, M.B., Hunt, G.L., Stockwell, D., Whitledge, T.E., Jump, M., Zeeman, S., 1998. Aquamarine waters recorded for the first time in eastern Bering Sea. EOS, Transactions, American Geophysical Union 79 (10), 121-126.

Varela, D.E., Harrison, P.J., 1999. Effect of ammonium on nitrate utilization by Emiliania huxleyi, a coccolithophore from the oceanic northeastern Pacific. Marine Ecology Progress Series 186, 67-74.
Verity, P.G., Stoecker, D.K., Sieracki, M.E., Nelson, J.R., 1996. Microzooplankton grazing of primary production at $140^{\circ} \mathrm{W}$ in the equatorial Pacific. Deep Sea Research Part II 43 (4-6), 1227-1255.

Whitledge, T.E., Malloy, S.C., Patton, C.J., Wirick, C.D., 1981. Automated Nutrient Analyses in Seawater. Brookhaven National Laboratory Formal Report BNL51398, Upton, New York, pp. 216.

Wolfe, G.V., 2000. The chemical defense ecology of marine unicellular plankton: constraints, mechanisms, and impacts. The Biological Bulletin 198 (2), 225-244.

Wolfe, G.V., Steinke, M., Kirst, G.O., 1997. Grazing-activated chemical defense in a uni-cellular marine alga. Nature 387, 894-897.

Wolfe, G.V., Levasseur, M., Cantin, G., Michaud, S., 2000. DMSP and DMS dynamics and microzooplankton grazing in the Labrador Sea: application of the dilution technique. Deep-Sea Research I 47, 2243-2264.

Young, J.R., 1994. Functions of Coccoliths. In: Winter, A., Siesser, W. (Eds.), Coccolithophores. Cambridge University Press, New York, pp. 63-83. 